\title{
CENSURA: RAZÃO DE ESTADO OU RAZÃO DE BANDO?
}

\author{
CENSORSHIP: STATE REASON OR GANG REASON?
}

Luiz Sergio Modesto

\begin{abstract}
Resumo:
Censura: Razão de Estado ou Razão de Bando? Esta pesquisa lum por objeto a relação diacrônica finomenologicamente quantificada entre o signo "censura" e seu "objeto" na semiose (ação signica) censória do corpo, assim como a recepção do signo "censura" pela Nomogogia latira, i.e., pela espécie lex de mando gráfico recepcionada pela Constituição Federal do Brasil.

A pesquisa objetiva observar, descrevendo, o objcto ambivalente da "função censória", partindo do genoma até sua manifestação corporal na conduta humana, nas suas sintaxes interétnicas, e na dinâmica das macrocoletividades brasileiras.

Sobre tal objcto o autor superporá o método complexo fisico-semiótico da Semioselogia, includente da funomenologia Física (Heisenberg, Bohr, Lao Tzy), da Signologia (Pcirce), e do Instrumento Operacional da Progmática (Modesto) em sintaxe com o método psicanalítico (Freud) e a Neurociência (Lau e Bartel; Cahill). Espera resultar discriminadas a autocensura e a heterocensura,conforme analitica adiante:

1. Censura: objeto ambivalente. Flexão desazo censório V semiose censória. 1.1. Coletividades censórias no planeta. Mosaico Emissor e Receplor por sim-sim. sim/não, não/sim, nâo-nâo. 1.2. Sonho: desacatos no mosaico censório vígil. 2. Censura dialetal. Signo em assimetrias coletivas. 3. Censura concentrada ordinária ou extraordinária. 3.1. Intermitência da coletividade-bando contrastando a coletividade-familia. 3.2. Intermitencias de coletividades-bando travestidas de coletividades-estado: índice de corrupção de uma etnia!
\end{abstract}

Palavras-chave: Antroposemiótica. Autocensura. Heterocensura. Coletividadefamília. Nominal coletividade-estado. Real coletividade-bando. Coletividade-Bando travestida de Coletividade-Estado. Razão de Estado. Razão de Bando. Corrupção.

Professor pós-doutorado com titulo de Doutor em Comunicação e Semiótica pela Pontifícia Universidade Católica de São Paulo. Doutor em Teoria do Estado pela Faculdade de Direito da Universidade de São Paulo. Mestre em Direito Constitucional pela Faculdade de Direito da Universidade de São Paulo. Assessor Científico ad hoc da FAPESP, Fundação de Amparo à Pesquisa do Estado de São Paulu $<$ luizsergiomodesto@ig.com.br> 


\begin{abstract}
:
Censorship: State Reason or Gang Reason? This research has for object the phenomenologically quantified diachronic relation between the sign "censorship" and its "object" in the censorial semioses (signic action) of the body, as well as the reception of the sign "censorship" by the Latin Nomogogy, i.e., by the species lex of graphic exact recepted by the Federal Constitution of Brazil.

The research objectifies observe, describing, the ambivalent object of the "censorship function" starting from the genom until its manifestation in the corporeal human conduct, in its interethnic syntaxes, and in the dynamics of the Brazilian macrocollectivities.

On such object the author will superpose the semiotics-physics complex method of the Semioselogy, including the Physics phenomenology (Heisenberg, Bohr. Lao Tzy), the Signology (Peirce), and the Progmatic Operational Instrument (Modesto) in syntax with the psychoanalytic method (Freud) and the Neuroscience (Lau and Bartel; Cahill). We hope to result discriminated the autocensorship and the heterocensorship, according analytic ahead:

1. Censorship: ambivalent object. Flexion censorial devoid V censorial semioses. 1.1. Censorship collectivities in the planet. Emitter and Receptor mosaic by yesyes, yes/no, nolyes, no-no. 1.2. Dream: rejections in the vigil censorship mosaic. 2. Dialectal censorship. Sign in collective asymmetries. 3. Concentrated ordinary or extraordinary censorship. 3.1. Intermittence of the gang-collectivity contrasting the family-collectivity. 3.2. Intermittences of gang-collectivities travestied of statecollectivities: index ofan ethnos corruption!
\end{abstract}

Keywords: Antroposemiotics. Autocensorship. Heterocensorship. Familycollectivity. Nominal state-collectivity. Actual gang-collectivity. Gang-collectivity travestied of the state-collectivity. State reason. Gang reason. Corruption.

1. Censura: objeto ambivalente

Flexão desazo censório V semiose censória

O objeto de nossa pesquisa é a relação fenomenologicamente quantificada entre o signo "censura" e seu "objeto" diacrônico na semiose (ação sígnica) censória. Este signo é aqui recortado historicamente dos idos da cisão do Império romano aos dias correntes. Com a queda de Roma em 476 , divide-se a superposição política em Império romano do Oriente, capital Constantinopla, e Império romano do Ocidente, capital Roma.

Deixamos para trás. desde a fundação de Roma em -753. a Reale $2 a$ (-VIII a -VI). a República (-VI a -I) e o Império (-I a V). Nesse periodo os latinos construiram sua espécie grafada de referente étnico do mando político próprio, desde a lex ("lei é o mundo geral do povo (...), proposta pelo magistrudo" Gilissen, 1995: 86), até a compilação das leges, doutrina e manual no suporte físico de um codex por 
Justinianus em 529 e 534, o Corpus Juris Civilis (Gilissen, 1995: 90-92; Larousse, 1995 : 3.388).

Essa construção étnica latina do signo "censura" coincide com a pretensão de mando da Igreja romana sobre os espólios profanos do Império romano do Ocidente, riquezas dúcteis, encobertas pela máxima dispersão da superposição política na Idade Média ocidental (V-XV), e, a partir do cisma de 1054, pretensão de mando reduzida à coadjuvância concorrencial.

É nesse século XI que o moroso conflito dogmático, disciplinar e ritualístico havido entre Roma e Constantinopla consuma perdido para a superposição politica dos ritos gregos da Igreja bizantina o Império romano do Oriente (Pierrard, 1982: 61-64, 83-89), íntegro até 1453, ano da tomada de Constantinopla pelos turcos e início da Idade Moderna.

Nesse contexto latino o signo "censura" foi "recuperado dos Romanos pelo Direito C'anônico a partir da Idade Média para catalogar o bricabraque das excomunhões, interditos e suspensões" da teologia cristã, retendo-se na lex a possibilidade de "pena (...) para curar a alma, uma pena medicinal" (Legendre, 1983: 34), pena passível de ser esculpida no corpo mediante o "uso da força contra o erro" por mando do papa Gregório IX (1227-1241) a partir de 1231 (Duffy, 1998: 115: Durant. 1971: 696).

Desde então, a coletividade-bando Igreja romana (ver subitem 1.1. fig. 2), autoproclamada "universal" ("católica" do grego katholikós), "enriqueceu" o legado de Gregório IX mediante a censura por genocidio com a lascívia da tortura, queima de hereges, expropriações, deletação de informações por referência no Index Librorum Prohibitorum ou por queima de livros pelo Tribunal da Inquisição (Duffy, 1998: 169).

A inquisição permanece hoje travestida e intermitente superpondo-se ao mosaico étnico de fiéis da Igreja Romana (Latina) por meio da Sacra Congregatio pro Doctrina Fidei, polícia politica a serviço do mítico e hierático mundo do Papa, o imperium do pai (grego páppas) de plantão no dominium da nominal coletividade-estado Cidade do Vaticano. (CDC, cânones 204, parágrafos 1 e 2, 1, 360, 1.404, 1.405, § l Wojtyla, 1983: 90, $2,168,612$ ) Entre os seus meios censórios in nomine dei, superpõe-se mediante os exemplos deletérios das penas do "silêncio obsequioso" e da proibição para reeditar livros (Boff, 1994 : 7, 343; Graieb, 2005: 85), como feito pelo ex-membro da Hiller-Jugend (Juventude Hitlerista). inquisidor de 1981 a 2005, e hoje autocrata dessa nominal coletividade-estado. o mandatário alemão Joseph Alois Ratzinger (Britannica. 2007: Hein. 2007: Sabino, 2005: 70), cujo lema episcopal de "Colaborador da verdade" contrasta com a biografia censurada no site do Vaticano (2007). 
No repertório contemporâneo de seus interpretantes triviais e dialetais (Modesto, 2005-a: 372-374), o signo "censura" como registrado no século XV, indicia o português medieval recuperando esse passado latino (Randum House, 1994; llouaiss, 2001 ) por suus interpretantes brasileiros "avuliar" "arrolur". denotativos de quale e cálculo.

Com o Renascimento (XV XVI), aquele componente sacro passa a ser dissimulado pela proposição instrumental dos legistas, profissionais do nómus ou mando da espécie latina lex que, serviçais de uma racionalidade política "leiga". contudo. não logram ocultar a escora teológica da "censura" como se pode observar no preâmbulo da Constituição Feuleral do Brasil, promulgada "sob a proteção de Deus" (Brasil, 2002), mando censório grafado superpondo a censura pusitiva ao dialeto monoteísta de uma coletividade e a censura negativa às demais coletividades politeistas, deistas, ateistas e indiferentes do território.

Sacro ou leigo, assim construido, u signo "censura" tem por objeto o ego ou o alter na retenção de uma conduta do próprio corpo vu de outrem, ou na submissão de objetos textuais informativos originados do espaço doméstico ao mando de outro por critérios divergentes da avaliação própria de conveniência na performance ou divulgação no espaço público e. ou. no próprio espaço doméstico. retenção do corpo ou submissão dos signos "uroludos" por "avaliução" censória em tempo real. preventivo ou repressivo, mediante critérios matizados do pessoalmente difuso, passando pelos dialetos do mercado, ao coletivamente concentrado.

O complementar oposto dessa "censura" dominantemente invasive ou yang e supressiva entre Emissor/Receptor (E/R), a censura negativa propriamente trivial (não/sim), observamos a censura positiva dominantemente complacente ou yin ( $\operatorname{sim}-\operatorname{sim}$ $\mathrm{V}$ não-não), limítrofe e similar à indiferença do desazo $(0-0 \mathrm{~V} \quad 0-1 \mathrm{~V} \quad 1-1 \mathrm{~V} \quad 1-0)$, na disposição ou na coordenação entre ulter e ego para condutas do corpo e objetos textuais informativos em comum partilhados E-R.

Os objetos textuais da informação são repertoriados pelo conhecimento trivial por meios da tradição oral e da scmiose jornalística. A semiose jornalística implica a atividade coletora, analítica e transmissora da informação mediante suportes diversos, meios de comunicação ou midias como o papel (jornal, revista, livro), o rádio (amplitude modulada $[\mathrm{AM} \mid$, freqüência modulada [FM]. onda tropical [OT]), o vídeo (televisão, internet).

No modo de produção jornalistica, a censura é designada e denotada na "avaliação" e no "arrolamento" seletivo de parte do conhecimento trivial. A essa commodity recortada e coletada do conhecimento trivial, a semiose jornalistica agrega o 
conhecimento dialetal das tribos informativas, como se pode exemplificar na censura positiva ao uso da força mediante palmada na infância como "justificável" (Veja. 2000: 94). ou na censura negativa mediante a asserção de que "Barba não inspira credibilidade" (Veja, 2007-2001: 50), "informações" sem suporte em hipóteses verificadas e controladas intersubjetivamente por quantificação empírico-racional produzida pelo conhecimento científico sensu stricto (Modesto, 2005-a: 373-374. 393 407).

De forma sintética, a "censura" objeto de nossa pesquisa fenomenologicamente quantitativa é a censura negativa e invasiva (não/sim), denota a probabilidade entre Emissor e Receptor em simetria (E-R) ou assimetria (E/R) no mando binário "não $\mathrm{V}$ sim" para a reprodução de uma ação ou de uma informação mediante conduta do corpo (relação objeto-signo) ou mediante representação (relação signolobjeto ou signo/signo).

Esse mando binário implica os complementares opostos de flexão do ego na relação com alter (ou alter-ego), cada qual um bit de informação singular dos possíveis desazo censório entre os sinsignos 0 ou $I$ ( $4^{\mathrm{a}}$ classe sígnica - Peircc, 1978-2.257: 147) e seus legisignos da semiose censória não ou $\operatorname{sim}\left(7^{3}\right.$ classe sígnica - Peirce, 1978-2.260: 148): "desazo censório alter-ego 0-0 V 0-I V l-I V l-0" V "ação censóría siminão" (fig. 1).

U "desazo censório" ( $O$ V I) implica a vitalidade da comunhão E-R em simetria (0-0) por não implicar censura mútua ("/") entre alıer e ego, mas implicar censura( $l)$ afetando terceiros $(0-I \mathrm{~V} I-I \mathrm{~V} I-0)$, ainda que simétricos ou assimétricos noutros conteúdos da ação complexa. É nessas contingências que o "desazo censório" apresenta a quale da "virtualidade signica" ou signânsia, complementar oposta da censura negativa (não) ou da censura positiva (sim) na ação dinâmica (diádica) do corpo e na ação signica, i.e., semiose (triádica) gestual, oral ou gráfica.

\begin{tabular}{|c|c|c|c|c|c|}
\hline & FLEXA & O CENSÓRIA COR & ORAL & & \\
\hline Emiwor-alter E Receptor-ego & intermitência & mando censurio & signânsia & repercussăo & กexão \\
\hline $0.0 \vee 0.1 \vee 1.1 \vee 1.0$ & simetria (-) & desazo censório (não-mutual) & vitalidade & quale-corpo & virtual \\
\hline $\operatorname{sim}-\operatorname{sim} \mathrm{V}$ não - não & simetria (-) & açãocensória- autocensura & ação dinàmica & corpo-signe & latente \\
\hline $\operatorname{sim} / n \tilde{o}$ & assimetria $(/)$ & superposição censória - heterocensura & ação signica & signo/corpo & \\
\hline manifesta & & & & & \\
\hline
\end{tabular}

Figura l Virtualidade e efetividade da ferão censória do ego em desazo ou em relaçào Emissor e Rcceptor

Partindo-se dessa forma sintética, por corte denotativo diacrônico, o signo "censura" independente da sua indicialidade signica registral do século XV, denota um 
objeto atemporal, freqüenta a própria condição das etnias humanas a partir do genoma, conjunto de genes combinados e seqüenciados linearmente em um par de cromossomas variável e característico de cada espécie animal ou vegetal, por meio de um mensageiro especial do DNA de cada célula cuja função é censória, o RNA de interferência (RNAi) que age em relação à expressão genética de um gene ameaçador à sobrevivência celular na sua reprodução, reprimindo tal expressão na transcrição celular do DNA (Lau e Bartel, 2003: 51-53; ver também Guimarães, 2007: 49).

A censura também freqüenta a condição humana na sua face visivel do corpo como censura difusa (Emissor-sim/Receptor-não), ou como ação simuladora ou dissimuladora para a sobrevivência (Smith, 2005: 33-34) corporal no seu esquema motor de assimilação empírica do outro a partir da coletividade-família e conseqüente repertório interpretante de acomodação latente da relação alter-ego, desde os domínios da sua propriocepção e autodiálogo ego-superego dominantes no espaço doméstico.

É na construção dessa relação do sujeito com o objeto ambiente que o ego (eu) censório instrumentaliza o nosso corpo, por gestos, fala ou grafia no sentido de não revelar ao alter (outro) nossas intenções no espaço doméstico ou no espaço público, empregando a mentira para o fim de subordinar o alter ao ego (Piaget, 1978: 298), mediante dissimulação ou simulação dos desejos do corpo e dos interesses de ganho da própria ação sígnica (signação), ego e corpo ambivalentes na ação dinâmica ou na ação sígnica com alter, até o limite castrador de substituir o desejo e seu gozo, caso da lex latina, dentre outras espécies de heteromando observadas e descritas na sua diversidade mundial pela Nomogogia (Modesto, 2005-a: 408-413), e para dissimular a verdade no discurso político (Legendre, 1983: 94, 117, 37).

Nessa extensão do corte pela teoria do conhecimento para focar a ambivalência do corpo entre o sim e o não censórios, observamos que a censura é um instrumento de sobrevivência, controle e replicação próprios dos reinos animal e vegetal no mercado biota; a censura freqüenta a dinâmica do corpo intermitindo na sua latencia ou manifestação no mercado econômico, o corpo na singularidade dos seus interpretantes emocionais e dominantemente indiferente à valoração negativa ou positiva do mercado político, na tensão dinâmica da força e das espécies étnicas de mando com a Nomogogia das nominais coletividades-estado no planeta. Sem a censura negativa, não se caça, não se reproduz, arrisca-se a sobrevivência.

Por corte sincrônico a censura entre etnias humanas indicia contrastes por mando e conflitos por força no mercado biota, no mercado econômico e no mercado político, onde os objetos e (con)textos de desejos vitais e, ou, interesses de acumulação 
que movem nossas intenções intercorporais disputam meios escassos para a satisfação dos ritmos biológicos neguentrópicos.

No corpo, o registro físico dessa disputa mediante "espinhas" dendríticas (Cahill, 2007: 48) associa neuronialmente em rede estímulos externos ou internos (E) a suas recepções perceptivas $(R)$ fundadas no hipocampo (interpretantes emocional e lógico) e amigdala (interpretante encrgético), redes integradas ao sistema límbico, na memória arquétria inconsciente ou primária emocional-energética-lógica (Modesto, 1999; Hülshoff, 2007: 14; Teicher, 2002: 56-57) acomodada nos esquemas motores mediante ritos corporais e legisignos ou convenções nomogógicos, i.e., conduta ou mando entre o nómos difuso e o nómos regional de suas respectivas generalizações, demarcados entre 式 shih, o exemplo corporal dos han, o writ casual dos anglos, e a crença causal e mecânica da lex dos latinos.

Aquele mando binário censor. nómos "não $V$ sim" na sua máxima subjetividade de expressão no ambiente do corpo descurado no sono, está presente no sonho, este. objeto da pesquisa e da metodologia psicanalítica pioneira de Sigmund Freud com resultados hoje validados experimentalmente pela Neurociência (Solms. 2005: 33: Solms, 2006; Leuzinger-Bohleber, 2006:48; Ribeiro, 2006: 23).

Esse métudo psicunalítico (Freud, 1981-97.2.9: 2.209) em sintaxe com a Neurociência, como vimos, e com o método complexo fisico-semiótico da Semioselogia,

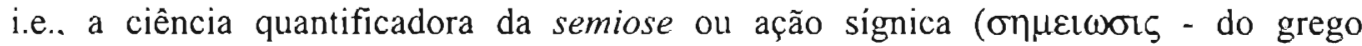
sérneiosis) includente da fenomenologia Física (Heisenberg, 1989: 34-35. 42-43: Bohr. 1995: 51, 65; Lao Tzy, s.d.; Lao Tzy, Inédito). da Signologia (Peirce. 1978-2.254-263: 147-149), e do Instrumento Operacional da Progmática enquanto interface entre Signologia e objeto pesquisado (Modesto, 1999), implementa hipóteses que indiciam fenumenologicamente coletividades interétnicas pela diversidade de seus ritos, legisignos e convenções durante a vigília. e coletividades intra-étnicas pela dinâmica de seus desejos e interesses territoriais.

É nesse locus singular da diversidade do corpo que o tomaremos como objeto de nossa pesquisa empírica na sua conduta censória ambivalente, observando-o a partir da mimetização dessa ambivalência da "censura", entre o desazo censório e a semiose censória de acato ou desacato ao mando nos sonhos que freqüentam o gênero humano no planeta. com recorte na etnia brasileira e a intermitência da sua lex, da autoccnsura à heterocensura, esta com a censura difusa, a censura dialetal e a censura concentrada. ordinária ou extraordinária.

\subsection{Coletividades censórias no planeta}


Mosaico Emissor c Receptor por sim-sim. sim/não. não/sim, não-não

Uma (c) coletividade étnica, ou o coletivo físico-fenomenológico no campo do domínio, está no conjunto fenomenológico aleatório, intermitente, e não reificável de Emissores $(E c)$ ou Receptores $(R c)$ atomizados, conjunto referido por distinta liberdade fenomenológica corporal ou intercorporal, quer implique a mente (liberdade da mente enquanto interpretante emocional), quer denote ou designe a vontade (liberdade da vontade enquanto interpretante energético), ou exprima qualquer espécie nomogógica de mando (liberdade na diversidade do nómos enquanto interpretante lógico).

O minimo coletivo intra-ćtnico pode ser observado como objeto empírico no tribalismo humano de qualquer coletividade-família entre mãe, pai e cria no seu espaço doméstico de relações eutímicas (horizontais) e políticas (verticais). (comparar com Ridley, 2000: 17I-219)

Por critério de domináncia macrofenomenológica, na seqüência físicosemiótica acaso-real-signo (Peirce, 1974-6.201: 137-138; 1978-1.325: 162-163; 19781.26: 8), o ego humano pode observar em qualquer mercado territorial étnico a segmentação dinâmica de até três coletividades disponiveis para sintaxes diádicas de superposição política nos espaços-tempos intercorporais doméstico e público: as coletividades família, bando. estado. A superposição política de quaisquer dessas coletividades subjugando as demais ocorre por E/R (Emissor/Receptor) mando/acato ou forçallesão, e procedivel justificativa (fig. 2).

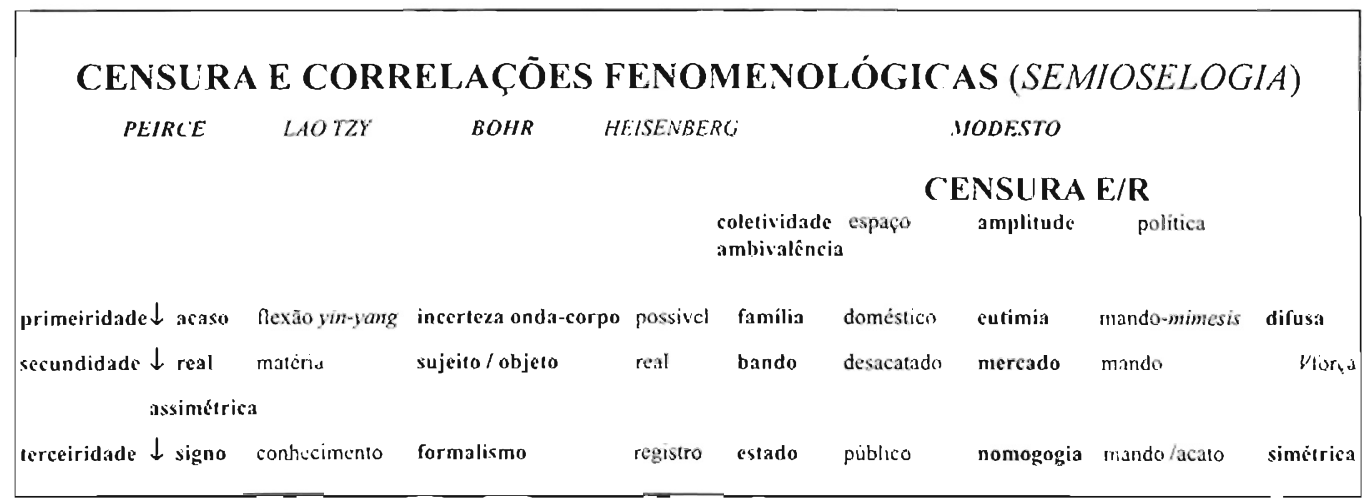

Figura 2 Fisico-semiótica da semiose censóric contre Emissor e Reccptor (E/R)

Observa-se a colefividade-familia na intermitente superposição política. cuja liberdade no espaço-tempo intercorporal tem por dominância o acaso e o desazo perpassados pela contigüidade corpo-corpo nas relações eutímicas de automando, e 
pelas relações propriamente políticas de heteromando na temporalidade local do espaço doméstico, não necessariamente o locus, mas a quale do afago e do tesão.

Observa-se a colctividade-estado na intermitente superposição política, cuja liberdade no espaço-tempo intercorporal tem por freqüencia simétrica com a coletividade-familia o automando e o heteromando e tem por dominância assimétrica a nomogogia - contemporânea ou extemporânea, local ou geral - perpassada pelas relações entre corpo e corpo na temporalidade geral do espaço público.

Observa-se a coletividade-bando na intermitente superposição política, cuja liberdade no espaço-tempo intercorporal tem por dominância a assimetria no desacato por contraste (no mando) ou por conflito (na força) com a coletividade-família no espaço doméstico e com a coletividade-estado no espaço público. (Modesto, 1999)

Tais coletividades macrofenomenológicas da familia, do bando, do estado. disponíveis para sintaxes diádicas de superposição política nos espaços-tempos intercorporais doméstico e público, enquanto circunstanciadas intra ou interetnicamente pelo plancta (Antroposemiótica), por vezes dessincronizam a cotidiana simetria "simsim" ou "não-não" no mando binário de superposição política da "censura"

Intra ou interétnicos, é nos casos da assimetria "alter-não/ego-sim" (fig. 3), quando o ego transpõc a irracional e despercebida autocensura "sim-sim" ou "nãonão" para suportar do alıer a censura dialetal do cotidiano (E-não/R-sim), que surge a purcepção cognitiva daquela ambivalência dinâmica da censura, percepção exacerbada no alto contraste macrocoletivo da censura concentrada emitida do espaço público. censura manifesta e diversa da censura latente por "sim/sim" ou "não-não" no ıspaço doméstico e difusa por "sim/não" na coletividade-familia e no espaço público.

\begin{tabular}{|c|c|c|c|c|c|c|}
\hline \multicolumn{7}{|c|}{ MIOSAICO CENSÓRIO INTRA OU INTERÉTNICO } \\
\hline E-alterVR-ego & intermitência & mand & o censor & reussāo & flexão & espaço-tempo \\
\hline $\operatorname{sim}-\operatorname{sim} \mathrm{V}$ não - não & simetria & autocensura:posit & iva $V$ negativa & corporal & latente & público -doméstico \\
\hline $\operatorname{sim} / n \tilde{o} o$ & assimetria & heterocensura: & - censura difusa & ubiqua & manifesta & público-doméstico \\
\hline$n \tilde{a} o / \operatorname{sim}$ & assinietria & - censura dialetal & $\begin{array}{l}\text { - censura concentrada: } \\
\text { ordinária } V \text { extraordinária }\end{array}$ & coletiva & manifesta & público $>$ doméstico \\
\hline
\end{tabular}

Figura 3 Dinâmica censória alter e ego e atributos entre Fmissor e Receptor $(E$ e $R)$

O "não" da censura dialetal que se superpõe puliticamente sobre as demais coletividades mediante a censura concentrada, emitida $(E)$ do espaço público na seqüência temporal com o receptor $(R)$, aglutina reciprocidades positivas de acato $E-R$ ("nãu-não") e reciprocidades negativas de desacato $E / R$ ("não/sim") ao censurado nas 
freqüências em que a sua recepção $(R)$ também é censória: $R$ censura negativamente a semiose censória negativa do $E$. ampliando a complexidade do contraste no mando. De latente no espaço doméstico, exsurgindo manifesta no espaço público, essa censura amplia a disponibilidade para o conflito por força; ao demandar motivação ou justificação do mando censório, a coletividade-familia problematiza a sintaxe com $E$-se nominal coletividade-estado: ruzão de estado?

Por esse corte descritivo, pode-se observar que a censura implica um mosaico planetário de composições e decomposições, não é uma ação unilateral de um "não" nomogógico, mas multilateral e dinâmica num contexto intra-étnico ou interétnico.Desconsideradas as intermitências da ambivalente censura dialetal "não/sim" e da censura difusa "sim/não" nos mercados biota, econômico e político, podemos observar a censura concentrada local ou regionalmente na denotação das coletividades fenomenológicas estado/familia por "E-alter-não/R-ego-sim": na intermitência da assimetria no mercado político, a nominal "coletividade-estado" decai para real "coletividade-bando" superpondo a coletividade-familia.

\subsection{Sonho: desacatos no mosaico censório vígil}

Diferentemente da flexão censória desazo-ação intermitente da vigília, é durante o sonho que a "função censória" do ego denota dominância no corpo (Freud, 1981-97.2.9: 2.206 e 2.207). A função censória exprime difusa ou coletivamente a dinâmica dos ritos corporais, dos legisignos e das convenções nomogógicos do superego trazidos da vigília, por mando complacente, obrigatório ou proibitivo do alter.

A censura onírica exprime a dinâmica diacrônica intra-étnica da censura em que um objeto de ação ou de informação ontem proibido (assimetria "não/sim") hoje compraz a uma etnia (simetria no desazo censório 0-0 e na complacência censória "simsim" item 1, fig. 1), caso da censura concentrada extraordinária via $18^{\mathrm{\lrcorner}}$ Emenda à Constituição dos Estados Unidos da América do Norte em 1919, que deu fundamento ao Volstead Act de 1920 proibitivo da conduta dialetal de acessar o corpo mediante os alter-mentes alcólicos (Lincoln, 1978-2: 2.129; Modesto, 1994), a Prohibition ou "lei seca" (18/01/20 a 05/12/33), revogada em 1933 pela $21^{\text {a }}$ Emenda. (Lincoln, 1978-1: 823; Kerr, 1999: 94; Istoé, 1998-3, 1998-4)

A censura onírica também exprime a dinâmica sincrônica interétnica da flexão censória em que um objeto proibido por uma etnia compraz a outra etnia (assimetria interétnica "não/sim"), caso do alter-mentes cannahis sativa proibido no Brasil (Decreto-lei n. 891, art. $1^{\circ}$. primeiro grupo, XVI Brasil. 1994: 16), mas não na 
Holanda (Stengers e Ralet, 1991: 18), o mosaico censório no planeta do qual se falou no subitem 1.I.

O sonho reflete essa alternância observada durante a vigília na ambivalência da "censura onírica" (Freud, 1981-972.9: 2.207-2.209), ( $($ ) implicando simetria nos acatos das espécies nomogógicas do mando que o ego-Receptor reproduz (E/R "não-não"), mediante resistências a desejos e interesses proibitivos para o ego-Receptor e para o alter-Emissor (1981-97.2.9: 2.207), e (2) implicando assimetria nos desacatos das espécies nomogógicas que o ego-Receptor rejeita para si (E/R "sim/não") ou para o alter-Emissor (E/R "não/sim"), mediante deformações oníricas justificadoras desses desacatos ao proibido (1981-97.2.9: 2.205, 2.207).

Estas censuras assimétricas mediante os desacatos no sonho indiciam as deformações quanto à utilidade das espécies nomogógicas da dominação política local ou regional em relação às condutas do corpo durante a vigília, deformações observadas entre o mando proibitivo da cannabis sativa pela in casu real coletividade-bando Brasil e o mando complacente da coletividade-família na freqüência do seu consumo eutímico no espaço doméstico (Modesto, 1994), denotando essa latência ou manifestação das condutas proibidas ao corpo, condutas antecipatórias ou reveladoras de proibições entropicamente em desconstrução por desacato ou complacência no decorrer diacrônico da história de uma etnia.

$\mathrm{Na}$ vigília, a censura difusa do ego implica as intermitências de desejos vitais e interesses de acumulação em disputa (cotejar Freud, 1981-97.2.9: 2.205), denota intenções nas relações assimétricas de mando/acato, enquanto o acato censório modulase da submissão tout court às simulações e dissimulações, e também exprime relações simétricas da censura prévia como escape ao censor (autocensura).

O objeto da censura no mercado político são as tendências (Freud, 198197.2.9: 2.207-2.208) do ego direcionadas à utilidade dos desejos (prazeres) e aos interesses (produtos) trocados na dinâmica do mercado econômico e do mercado biota. É na fluidez do sonho no mercado biota que vencemos as resistências econômicas e políticas e satisfazemos a quale da impressão sem objeto qual alucinação de tais desejos (1981-972.9: 2.203, 2.205, 2208) e interesses, desacatando as espécies nomogógicas de mando censório negativo que censuramos na vigília das relações políticas de dominação no mercado econômico e no mercado político (assimetria "não/sim"), implicando a latência ou a frequêencia daquelas ações ou informações complacentes ou proibidas durante a vigília.

\section{Censura dialetal}


Signo em assimetrias coletivas

$\mathrm{Na}$ heterocensura, tanto a censura dialetal, quanto a censura concentrada (ver subitem 1.1, fig. 3), ambas são processadas "E-não/R-sim" por meio do conhecimento dialetal, "conhecimento compartilhado (...), [que] implica o conhecimento local ou regional de uma coletividade prática ou teórica mediante a dominância de interpretantes energéticos (Peirce, 1974-5.475: 326) por racionalização assimétrica de 'autoridade não se fundamentando dominantemente no empíricoracional de um objeto quantificado, mas na probabilidade da convicção subjetiva da indução pessoal ou do argumento indutivo casual (empírico [...]) ou do argumento indutivo causal (reflexivo [...])" O conhecimento dialetal "é problemático no alcance das relações interpessoais no limite coletivo dos naipes de dominação no mercado econômico e no mercado político" (Modesto, 2005-a: 372).

O mando gráfico da espécie nomogógica designado "lei" da etnia brasileira, retalho dedutivo da lex latina, na versão máxima in genere da Constituição Federal (CF), no título II relativo aos "direitos e garantias fundamentais", capítulo I dos "direitos e deveres individuais e coletivos", valoriza positivamente (censura positiva sim-sim V sim/não) a semiose de desacato do corpo à censura na proposição de que "é livre a expressão da atividade intelectual [ação signo-objeto ou signo-signo], artística [ação signo/signo ou signo/objeto], científica [ação objeto-signo] e de comunicação [ação signo-signo], independentemente de censura ou licença" (CF, art. $5^{\circ}$ IX - Brasil. 2002).

Esta proposição censória complacente "sim-sim", confinante com o desazo censório "0-0" no espaço doméstico ou no espaço público (ver item 1, fig. 1). refere valorizar positivamente o acato da reprodução de informações ("expressão" signo-objeto ou signo-signo) do conhecimento trivial ("comunicação"), do conhecimento dialetal ("atividade intelectual e artística") e do conhecimento científico ("atividade cientifica"), de resto, reprodução acausal dominantemente problemática para um controle potente e competente de uma coletividade-estado no espaço doméstico, como indicia o "verba volant" do conhecimento trivial.

Tal proposição censória, contudo, não refere valorizar positivamente ( $\operatorname{sim}$-sim V sim/não) o desacato do corpo à ação dinâmica retendo censoriamente a própria conduta (ação corpo-signo da autocensura) ou à semiose retendo censoriamente outra conduta (ação signo/corpo da heterocensura difusa, ou dialetal), vale dizer, essa lex desacata (censura negativa: não/sim) a heterocensura concentrada coletivamente, de 
problemática sustentação econômica e política, indiferente à autocensura, à censura difusa e à censura dialetal freqüentes.

Observa-se nestas pontuadas indiferenças da lex à censura, o mero e efetivo acatamento das superposições políticas censórias do cotidiano com: (l) a assimetria "não/sim" da censura dialetal na semiose entre coletividades no mercado econômico, aquela que se dá quando a nominal coletividade-estado não veicula publicidade institucional em um jornal da oposição; (2) a assimetria " $\operatorname{sim} /$ não da censura difusa inferida das condutas dos corpos na relação com essa coletividade midiática por ação dinâmica corpo-signo, aquela que se dá quando os demais executivos de empresas anunciantes nesse jornal assimilam ali também não anunciar, temendo retaliação da nominal coletividade-estado (Mattos, 2005: 139); (3) a simetria "sim-sim" ou "não-não" da autocensura positiva ou negativa, quando jornalistas condenados por "delitos de opinião" contagiam outros no descurar do jornalismo investigativo (Mattos, 2005: 166).

No título VIII, "da ordem social" capitulo V "da comunicação social", essa indiferença da Constituição Federal permanece quanto à autocensura, contudo deixando de existir em relação às heterocensuras difusa e dialetal, passando a ser valorizado positivamente ( $\operatorname{sim}-\operatorname{sim} \mathrm{V} \operatorname{sim} / n a \tilde{o})$ o acato do corpo às censuras do mercado econômico e do mercado político. Como?

$\mathrm{O}$ art. $220, \S 2^{\circ}$, é aparentemente paradoxal em relação a essa asserção e porque simula vedar tout court a censura, reiterando o art. $5^{\circ}$, IX, contudo o que propõe é o desacato seletivo à heterocensura concentrada: "É vedada toda e qualquer censura de natureza politica, ideológica e artística" Superada a aparência paradoxal, os demais dispositivos de mando do título assumem valorizar positivamente o acato da censura dialetal, contudo dissimulando-a pela ocultação do signo "censura", mas não de seu objeto censório ambivalente do corpo na ação dinâmica de retenção de uma conduta e na semiose de submissão de objetos textuais informativos.

A reiterada censura concentrada do emissor nomogógico é referida como vedada às coletividades do mercado político ("nenhuma lei" - art. $220, \S 1^{\circ}$ ) e do mercado econômico ("sob qualquer [...] veiculo" - art. 220, caput), aqui pontuando com mais ênfase o conhecimento dialetal das liberdades "política, ideológica e artística"

Censurada a heterocensura concentrada por coletividade macrofenomenológica no art. $220, \S 2^{\circ}$ a Constituição Federal viabiliza a censura dialetal fundada na autoridade, aquela que não é percebida como censura concentrada extraordinariamente. como apontamos no subitem 1.1 relativamente à lex censória do ucessar o corpo mediante cannabis ou álcool (Modesto, 1994), bem assim viabiliza a censura difusa, mediante o eufemismo sintático da parataxe. 
Por esse artificio persuasivo, o artigo 220 proibe a "restrição" à "manifestação do pensamento, a criação, a expressão e a informação, sob qualquer forma, processo ou veículo" mas por meio de genérica parataxe, "observado o disposto nesta Constituição" implica recepcionar a censura difusa e a censura dialetal expressas no art. $5^{\circ}, I V, V, X, X I I I, X I V$, referido no art. $220, \S 1^{\circ}$, e expressas no art. 220 , parágrafos $3^{\circ}$ e $4^{\circ}$.

A censura, nesses distintos dispositivos de mando, viabiliza a função de verossimilhança ao valorizar positivamente a semiose de desacato do corpo à censura na proposição "sim-sim" de acato à reprodução de informações prevista no art. $5^{\circ}$ IX, diferindo mediante parataxe a censura difusa e a censura dialetal para os dispositivos acima apontados. Declara "direitos e deveres individuais e coletivos" no capítulo I, do titulo II, intróito de valores do mercado econômico que o mercado político constitucionalmente garantiria, para desconstruir tais direitos em dispositivos diversos.

"A função de verossimilhança relaciona o domínio objeto real de um Signo, travestindo-o da imagem referente verbal deste Signo no código verbal. A qualidade do objeto real do Signo ["é livre a expressão" - CF, art. 5० IX] é adjudicada ao referente verbal deste Signo por designação ["independente de censura" - CF, art. $5^{\circ}$, IX], não se verificando necessariamente a denotação do Signo apontado [a "independência de censura"]. O Signo designa e não denota necessariamente. O efeito prático da função de verossimilhança está na onipotência da sua designação e na impotência predominante da sua denotação. A utilidade do recurso está na possibilidade persuasiva do referente em ocultar a improbabilidade demonstrativa do objeto" (Modesto, 1996: 109-110).

Pode-se observar essa desconstrução constitucional da "independência de censura" no acato à censura difusa: com a "vedação do anonimato" na "manifestação do pensamento" ( $\mathrm{CF}$, art. $\left.5^{\circ}, \mathrm{IV}\right)$; no acato à censura dialetal freqüente na mediação interventiva dos conflitos pela "jurisdição": com a censura econômica da "indenização" ao problemático "dano material, moral ou à imagem" por "agravo" na informação verbal ou midiática (V), ou por "violar" a "intimidade, a vida privada, a honra e a imagem das pessoas" (X), mesmo que num e noutro casos essa imagem pública seja construída em desconformidade com seu objeto no espaço doméstico.

A censura econômica $\left(\mathrm{CF}\right.$, art. $5^{\circ} \mathrm{V}$ e $\left.\mathrm{X}\right)$ pode ser utilizada para censurar a pesquisa e seus resultados (art. $5^{\circ}, I X$ ) mediante a instrumentalização da mediação interventiva dos conflitos pela "jurisdição" e para os fins particulares de construir um mito mediante uma imagem pública asséptica, para tanto expurgando fatos cotidianos tidos por desfavoráveis à essa construção, como ocorreu com o cantor espírito-santense 
Roberto Carlos Braga, que censurou a pesquisa do historiador e jomalista Paulo César de Araújo, publicada em São Paulo no ano de 2006, editora Planeta, na forma de uma biografia titulada "Roberto Carlos em detalhes"

Esse cantor que "sempre expôs publicamente tudo da sua vida, seus dramas e sentimentos" por meio de canções (Araújo, 2007: 9, 8), teria, contudo, se incomodado com "a narrativa do acidente de infância em que perdeu parte de uma perna, as revelações sobre sua vida sexual", que "nunca foi muito exigente em termos de mulheres. Qualquer uma que aparecesse (...) servia"” conforme relata o mordomo, bem como o "relato da agonia de sua mulher (...) que morreu de câncer" (Teixeira, 2007: 120), além de interpretações idiossincrásicas sobre "orgias", "um escândalo que envolvia menores e que abalou" o meio musical da época (Araújo, 2007: 9), todos "fatos conhecidos e previamente publicados pela imprensa, o que derruba a alegação de invasão da privacidade", como argüida (Teixeira, 2007: 120).

Mediante "acordo" obtido entre o cantor censor ao modus Goebbels, a editora e o pesquisador coagido por ação criminal em São Paulo, "acordo" extorquido mediante ameaça de dano empresarial e financeiro por ação cível movida no Rio de Janeiro, o livro objeto de uma pesquisa de quinze anos foi $\mathrm{cm} \mathrm{27/04/07}$ proibido definitivamente de ser produzido e comercializado, além da entrega dos exemplares existentes em estoque para destruição. (Teixeira, 2007: 120; Araújo, 2007: 7 e 8)

"O estarrecedor é que a censura não decorreu_de um ato autoritário, costurado às escondidas da Justiça. Foi selado dentro de um tribunal! Na presença de um juiz! E promotor! Será que um juiz pode promover um acordo que fere um direito constitucional? Criamos a censura legal!" A ditadura judiciária?"

"A burrice de Roberto Carlos e a indigência da Justiça, associadas à covardia da editora Planeta" (Petry, 2007: 53) também implicaram censura à liberdade de "expressão da atividade intelectual, artística, cientifica e de comunicação" expressas na Constituição Federal, particularmente em relação à pesquisa histórica (art. $5^{\circ}$, IX - Brasil, 2002), denotando, com tal censura concentrada extraordinária, a superposição política dessa coletividade-bando: o cantor, a editora e respectivos advogados, o juiz e o promotor.

Também sc observa a desconstrução constitucional da "independência de censura" no acato à censura dialetal de segmentos profissionais, mediante a censura estamental das "qualificuções profissionais que a lei estabelecer" para o acesso ao "exercicio de qualquer trabalho, oficio ou profissão" (XIII), ou mesmo o acesso à "fonte" de uma informação (XIV).

A censura dialetal, na medida freqüente em que se fundamenta na lex. como na retenção da conduta dialetal de acessar o corpo mediante alter-mentes 
(subitem 1.1), abre espaço para motivações e justificações que sistematizam a fabulação do conhecimento dialetal de legistas, e nesses casos pode dissimular o mando censório pela rubrica palatável e coonestadora do "poder de policia" (Faria, 1981: 84).

Ao contrário da proposição constitucional de desacato à censura, e da crença legista da "falta de previsão constitucional para o exercicio formal da censura" (Bastos, 1989: 84) induzida pela função de verossimilhança da lex, os mandos apontados implicam e denotam, sem exprimir o signo, previsão constitucional para a intermitência de seu objeto na censura difusa e na censura dialetal.

O que se observa da analítica físico-semiótica acima e até aqui é que a engenharia constitucional desacata no gênero o signo censura, simulando uma realidade paradisíaca de liberdade não observada pela Neurociência e pela Antroposemiótica, implicando "publicidade enganosa" (ver subitem 3.1). A publicidade constitucional apontada denota desconformidade com a indeterminação da semiose censória e seu objeto ambivalente, contraria a realidade censório-motora da sobrevivência cotidiana, descarta o mando público da censura concentrada, para admiti-la na heterocensura difusa e dialetal, assumindo reconhecê-la concentrada ordinária ou extraordinariamente em casos de conflitos latentes ou manifestos (como observaremos adiante e por último), mas não assumindo censurar concentrada e extraordinariamente a conduta dialetal de acessar o corpo mediante os alter-mentes que proibe por lex denotando coletividade-bando.

\section{Censura concentrada ordinária ou extraordinária}

\subsection{Intermitência da coletividade-bando contrastando a coletividade-família}

Observamos nos itens anteriores que a censura implica um objeto ambivalente "sim $V$ não" na ação dinâmica e na semiose do ego em relação ao próprio corpo ou em relação ao alter, freqüentando a própria condição humana do corpo animal na autocensura e nas heterocensuras difusa, dialetal e concentrada ordinária ou extraordinária a partir do esquema motor de assimilação empírica do alter qualificado pela memória primária do arquétrio inconsciente emocional-energético-lógico (Modesto, 1999: Hülshoff, 2007: 14; Teicher, 2002: 56-57), censuras não necessariamente racionais, úteis ou coerentes, pessoal ou coletivamente, intra ou interetnicamente: o ego censura o alter e não admite ao alter censurar, mas, quando é conveniente negociar, recepciona a censura de alter, mediante condutas de submissão, simulação e dissimulação para a satisfação de desejos e interesses de sobrevivência e reprodução do corpo. 
Resta analisar a censura no limite em que sai da penumbra do irracional cotidiano da censura latente no mercado biota, ou da cotidiana censura dialetal no mercado econômico e no mercado político, como observamos até aqui, para ser cognitivamente percebida mediante a censura concentrada fluindo entre ordinária e extraordinária nos contrastes coletivamente expressos "não/sim" por clivagem macrofenomenológica no mercado econômico e, ou, no mercado político. Exemplo: o coronel Hugo Cháves, preposto presidente da nominal coletividade-estado Venezuela, que em 27/05/07 "não" renovou a concessão transmissiva da Rádio Caracas Televisão (RCTV), a emissora mais freqüente em tempo real no espaço doméstico, contrastado como coletividade-bando pelo "sim" de $80 \%$ da coletividade-família contrária a essa censura concentrada extraordinária. (Costas, 2007; Teixeira, 2007)

É nesse momento intra-étnico extraordinário que se opõem territorialmente emoções ou razões distintas na díade censória "não/sim", quando a Antroposemiótica observa a ruptura da simetria nomogógica entre a coletividadefamília e o mercado, ou entre a coletividade-família e a expectada coletividade-estado (ver subitem 1.1, figuras 2 e 3). Na lex brasileira essa ruptura é prevista mediante a dissimulada delegação censória cotidiana à coletividade empresarial, ao executivo e judiciário da nominal coletividade-estado, e, tanto no ordinário das "diversões $e$ espetáculos públicos" (CF, art. 220, $§ 3^{\circ}, \mathrm{I}$ ), da "programação das emissoras de rádio e televisão" (art. 221) e da vedação aos "meios de comunicação (...) [o] monopólio ou oligopólio" (art. 220, $\$ 3^{\circ}$ ), quanto no extraordinário dos conflitos macrocoletivos do "estado de defesa" (art. 136, $\S 1^{\circ} \mathrm{I}, a, b, c, \S 2^{\circ}$ )e do "estado de sitio" (arts. 137, 138, 139, I a VI, e parágrafo único).

Esse rompimento, que implica superposição política da real coletividadebando contrastando como empresária, ou travestida de nominal coletividade-estado, como quantificaremos fenomenologicamente adiante, pode ser observado no cotidiano da censura concentrada ordinariamente ocorrente por meio da legislação federal: ao "regular as diversões e espetáculos puiblicos" quando informa "sobre a natureza deles, as faixas etárias a que não se recomendam, locais e horários em que sua apresentação se mostre inadequada" (CF, art. 220, \$3, I)mediante "classificação por adequação" (Lei n. 8.069, de 1990, art. 75 - Brasil, 1990: 13); ao "estabelecer os meios legais que garantam à pessoa e à familia a possibilidade de se defenderem de programas ou programações de rádio $e$ televisão que contrariem o disposto no art. 221, bem como da propaganda de produtos, práticas e serviços que possam ser nocivos à saúde e ao meio ambiente" (II).

Os critérios "informativos" para fundamentar a intermitência da censura referidos nesse art. 221 não são tecnicamente neutros, implicam o mosaico censório 
intra-étnico brasileiro por atendimento preferencial "a finalidades educativas, artísticas, culturais e informativas" (I), "promoção da cultura nacional e regional e estimulo à produção independente que objetive sua divulgação" (II), e "regionalização da produção cultural, artistica e jornalística, conforme percentuais estabelecidos em lei" (III). Trata-se de "informação" indutora de censura dialetal pela legislação federal.

Nesse caso, valem os "critérios" censórios tribais dos meios comunicativos de maior penetração no territónio - oligopólio-quase-monopólio. " A influência das empresas de comunicação é enorme"', admite José Eduardo Flias Romão, Diretor do Departamento de Justiça, Classificaçăo, Títulos e Qualificação, do Ministério da Justiça. Para ele, “ 'É muito mais fácil um governo privilegiar a TV Globo [acatar a superposição censória desta] do que cometer uma arhitrariedade contra ela [superpor a censura da nominal coletividade-estado]. E isso vale para qualquer governo"'. (Krieger, 2007: 43)

Para os profissionais da intermitente censura dialetal jomalística, sintomaticamente "a prática classificatória (...) não pode ser considerada cćnsura, uma vez que não veta" (Mattos, 2005: 127), chegando-se mesmo a titular matérias que tratam da "classificação indicativa dos programas de televisão (...) que alterou os critérios de classificação por horário e faixa etária" (Portaria n. 264, de 09/02/07, do Ministério da Justiça: Brasil, 2007-a) como "nada a ver com censura"!, mesmo "podendo ser realizada previamente" (art. 4", parágrafo único, I), dissimulando o signo "censura" no "ideal (...) [de] que as próprias redes encontrassem uma forma de controlor seu conteúdo" vale dizer, autocensura (Veja, 2007-1996: 75).

Essa censura "realizada previamente" expressa o interesse de 57,9\% da coletividadefamilia (Erthal, 2007: 22), contudo prevaleceu a "autocensura" da coletividade midiática, reivindicada pelas pressões da Rede Globo de Televisão (Carta, 2007-458: 15), pela Associação Brasileira das Emissoras de Rádio e Televisão (Abert), c acatada pela Portaria n. 1.220, de 11/07/07 (Brasil, 2007-b), que revogou a "censura prévia" denotativa daquele interesse da coletividade-familia. Fssa portaria manteve a censura a posteriori - não-efetiva em tempo real! - concentrada extraordinariamente no "monitoramento" da nominal coletividade-estado, probabilizando a censura em tempo real concentrada ordinariamente pelos dialetos tribais da região Rio-São-Paulo e denotando a superposição política da coletividade-bando midiática.

Como se observa, ao superporem-se politicamente os critérios das tribos midiáticas em relação à coletividade-familia, dominam os critérios "informativos" tecnicamentenão neutros ( $\operatorname{sim} / n a ̃ o ~ V$ não/sim), dada a carência de biunivocidade (sim$\operatorname{sim} \mathrm{V}$ não-não) entre emissão e recepção censória.

A "classificação indicativa" contudo. implica uma efetiva "censura classificatória" por faixas etárias até os $10,12,14,16$ e 18 anos e fusos horários de exibição 
televisiva (art. 17, I a VI e 19, parágrafo único), como admite a doutrina nomogógica da espécie lex (Silva, 2005: 254), e, mesmo que seja indicativa para as diversões públicas e os programas de rádio e televisão ( $\mathrm{CF}$, art. $21, \mathrm{XVI})$, tais semioses denotam o veto censório. Como?

A "classificação por adequação" entre informação e faixa etária é produto de uma avaliação subjetiva e amadora (cotejar Valladares, 2005: 150, 152), visto não quantificar os dados lesivos à infância em relação à recepção televisiva de "sexo e violência" (art. 17), sequer indiciando uma amostragem das censuras dialetais do território, mas denota veto censório ao invadir o espaço doméstico e suprimira avaliação motivada por contigüidade da coletividade-família, pela avaliação emocionalmente imotivada na superposição política por intermitência da nominal coletividade-estado e real coletividade-bando Brasil, noutros termos, desautoriza-se o interpretante emocional dos pais pela burocracia não quantificada e inexperta do censor.

O Estatuto da Criança e do Adolescente, Lei n. 8.069, de 1990, por essa "classificação" subjetiva da "autoridade", explicitamente censura a presença da criança e do adolescente fora da faixa etária indicada, ao restringir o "acesso às diversões $e$ espetáculos públicos classificados como adequados à sua faixa etária" e simula a possibilidade de que tal acesso se dê a "crianças menores de 10 (dez) anos (...) quando acompanhadas dos pais ou responsável" (art. 75 e seu parágrafo único Brasil, 1990: 13).

"Na prática (...) os pais terão grande dificuldade em encontrar uma sala de exibição que lhes permita tomar essa decisão. Amparados no (...) Estatuto da Criança e do Adolescente, os juizados da Infância e da Juventude muitas vezes punem com multas, vu uté interdição, estabelecimentos que abrem suas portas para pessoas mais jovens do que o previsto pela classificação indicativa, ainda que acompanhadas de um pai ou uma mãe. Para não serem caracterizadas como infratoras, as grandes redes exibidoras se antecipam e transferem para o porteiro o papel de censor. (...) Muitos juizes de comarca vêem nos dispositivos do Estatuto da Criança e do Adolescente (...) uma autorização para dar à classificação indicativa força de censura" (Valladares, 2005: 150. 152)

$\mathrm{Na}$ dinâmica das heterocensuras no mercado econômico, observa-se a fluidez entre as assimetrias da censura difusa e das censuras dialetais, quando essa diversidade aflui para a assimetria da censura concentrada, na sua carência de 
biunivocidade, fluindo entre ordinária e extraordinária por meio do oligopólio-quasemonopólio nos meios de comunicação em território brasileiro.

Esse oligopólio-quase-monopólio, tanto explora us meios de recepção passiva da informação (yin), casos do rádio e da televisão. que recepcionamos por acesso ordinário, cuja interatividade é residual e com dominância dos interpretantes emocionais, i.e, interrompe-se com perda de conteúdo, mas não se detém o fluxo dos dados emitidos na superposição política, quanto explora os meios de recepção ativa da informação (yang), casos dos jomais, revistas e livros que recepcionamos por acesso extraordinário, cuja interatividade é dinâmica com dominância dos interpretantes lógicos, i.e.. interrompemos ou retomamos sem perda de conteúdo o fluxo dos dados emitidos por coordenação eutímica ou política.

Entre o desazo censório e a ação censória (ver subitem 1.1. fig. 1), o oligopólio-quase-monopólio no mercado econômico administra por tais meios de informação a comunicação das censuras condicionais de nossas expectativas sob a perspectiva dos próprios desejos e interesses empresariais e políticos. com o suporte coonestador e simulador de imparcialidade alavancado pela Constituição Federal. ao menos "publicidude enganosa" (Lei n. 8.078. de 1990, art. 37, §1º- Brasil. 1991: 11). porquanto a informação é falsa em relação aos dados da realidade e induz o consumidor político a erro (crença na "vedação a monopólio ou oligopólio" CF. art. 220,5", IX), como observaremos quantificado.

O mando na forma lex simulador dessa imparcialidade e dissimulador das apropriações dos meios de comunicação por intermitentes tribos empresariais da coletividade-bando é o art. 220, § 5': "Os meios de comunicação social não podem, direta ou indiretumente, ser objeto de monopólio ou oligopólio" O texto censura negativamente ("não/sim") o monopólio ou o oligopólio dos meios de recepção passiva (rádio e televisão) e ativa (jornais, revistas, livros) da informação no mercado econômico, mas de plano é indiferente à censura dialetal econômica ("não/sim") dos meios de recepção ativa expressos no art. 220, $\S 6^{\circ}$ : "A publicação de veiculo impresso de comunicação independe de licença de autoridade"

Esse mando da lex desacata a censura dialetal política da "licença de uutoridade" mas acata a censura dialetal econômica implicada na formatação da informação em, ou acerca de, livros, caso da ABNT (Associação Brasileira de Nonnas Técnicas).

Essa empresa disponibiliza num murcado restrito aos associados eresidualmente aos interessados o produto "Projetos de "Vorma" de uniformidade na formatação da informação autoral, "norma" travestida de lex pública, ostentada na sigla 
"NBR" seguida de numeração seqüencial, "N" de "Norma", simulando oficialidade na sintaxe com "BR". de "Brasil"

O produto empresarial da ABNT instrumentaliza os editores do território brasileiro na esterilização censória da alteridade na formatação da informação autoral enquanto publicada nos livros (compulsar ABNT, 2002: 1-3, 16, 21, passim), denotando e exprimindo excluir a competição na diversidade e a sintaxe de "formas" no mercado, v.g., alinhamentos, recuos, seqüência de dados, recursos tipográficos (grifo, itálico, negrito), sinais de pontuação (aspas), e a liberdade na escolha de outras convenções (Mattar, 2005: 206-207) na formatação da informação.

$\mathrm{Na}$ intermitência, tais "normas" censuram a liberdade na pesquisa e na criação do autor de formatar a própria informação que pretende publicar (CF, art. 206, II), e censuram a liberdade de expressão (CF, art. $5^{\circ}$, IX; Lei n. 9.610, art. $7^{\circ}, \S 3^{n}$ art. 24, IV - Brasil, 1998: 40, 81) no subjugo do autor ao diktat dialetal da polícia editorial.

A censura dialetal econômica também é acatada na edição tribal da informação dos jormais diários, adquiridos no seu conjunto por apenas $5,2 \%$ dos habitantes (dados de 2004: Mattos, 2005: 145). Tais jornais exprimem a censura dialetal concentrada em seus editoriais e colunas políticas, podendo fluir da diversidadeda censura dialetal do cotidiano para a censura concentrada extraordinariamente nas superposições políticas macrofenomenológicas em sinergias vitimadoras como eleição territorial ou matança por homicídio bélico.

Observou-se a censura dialetal concentrada extraordinariamente nos jornais no caso eletivo de Lula ou Alkmin em 2006 no Brasil. quando os jornais estiveram em assimetria com a coletividade-família. e no caso da intermitência da coletividade-bando Estados Unidos da América do Norte na preposição de George Walker Bush superpondo matança à coletividade-família do Iraque. a partir de 2003. quando os jornais de início estiveram em simetria com essa coletividade-bando no genocídio (Paulo. 2003: A 16).

Levando-se em conta que a semiose jornalística não é livre, mas determinada por interesses econômicos vocalizados por tribos regionais, não podendo o jornalista assalariado tomar "as decisões sobre o que publicar ou não dentro do processo produtivo" (Lima. 2006: 155). e uma vez que sua interação crítica com as coletividades brasileiras não é vertical. mas horizontal e dominantemente restrita à coletividade dos próprios pares (2006: 172), pode-se melhor avaliar a freqüência da simulação no jornalismo ao veicular a autoimagem da "imparcialidade e objetividade" na "opinião-verdade" que "refletiria a pluralidade e a diversidade de opiniões" existentes no território (2006: 44), com "correção, isenção e pluralismo" (Kamel, 2007). 
Essa imagem de imparcialidade e objetividade busca dissimular a tropia pela censura observada no conhecimento dialetal produzido pelo jornalismo, mimetizando a tropia pela liberdade própria da produção do conhecimento científico. É o caso da Rede Globo de Televisão, que por meio do ato falho de seu diretor de plantão Ali Kamel (2007), "testa a hipótese" político-partidária de segmentos do seu público consumidor de implicar a nominal coletividade-estado Brasil, faceada por seu preposto Luiz Inácio Lula da Silva (PT), pelo acidente de um Airbus da TAM, com estimadas 200 mortes ( 186 a bordo) em 17/07/2007, próximo ao aeroporto de Congonhas, São Paulo.

"Testar hipóteses" implicativas revela a estratégia de manter refém o objeto da informação objetivando superposições política e econômica (Modesto, 203: 519), e aqui denotou a parcialidade e subjetividade do "padrão globo" ao amplificar indutivamente a oposição política, mediante a mimese da linguagem científica no laboratório inapropriado da semiose jornalística. À commodity coletada do conhecimento trivial (ver item 1.), a semiose jornalística agrega na logofatura ou na videofatura do produto a mimese do controle por inferência objetiva do conhecimento científico, ocultando a inferência subjetiva da censura política para qualificar de mando crivel a informação que veicula.

A dominação política instrumentada pela censura dialetal em terra brazilis também pode ser quantificada. No ano de 2000 publicavam-se 2.245 jomais, 465 deles diários (Mattos, 2005: 143), no entanto, mais de "70\% do clipping diário da 'mídia impressa produzido pela Radiobrás e distribuido, por assinatura, para o alto escalão dos poderes Executivo, Legislativo e Judiciário, em Brasilia, é proveniente de apenas quatro jomais considerados de 'temática nacional"', na seqüência, O Globo (tribo Marinho, Rio de Janeiro, circulando 274.934 exemplares-dia), Folha de S. Paulo (tribo Frias, São Paulo: 307.937 exemplares-dia), Jornal do Brasil (tribo Nascimento Brito, Rio de Janeiro: 75.800 exemplares-dia em 2004) e $O$ Estado de $S$. Paulo (tribo Mesquita, São Paulo: 230.859 exemplares-dia) (dados de 2005 - Lima, 2006: 166, 167).

Desconsideradas as redundâncias nessa produção jornalística de 2.245 jornais, tais números denotam que a nominal coletividade-estado Brasil é pautada pela censura dialetal da mídia por 4 tribos de 2 estados da federação na intermitente dominação política territorial.

Dentre os veículos impressos, as revistas semanais, dominantemente empresariadas no Rio de Janeiro e em São Paulo, também denotam concentração indiciada em 60\% com as tribos Marinho (Globo) e Civita (Abril). (Mattos, 2005: 139140,142 ) Jornais e revistas, meios de recepção ativa da informação, são os de mais baixa freqüência no mercado, contudo, de mais alta densidade informativa. Implicam um 
repertório de autoridades dialetais indutoras das expectativas condicionadas dos conhecimentos trivial e dialetal (Modesto, 2005-a: 373), na incerteza da sintaxe entre emissor e receptor.

Aquela simulação de imparcialidade política do art. $220, \S 5^{\circ}$, é coadjuvada pela dissimulação da exploração econômica da heterocensura concentrada ordinariamente expressa no art. 21, XII, a, que atribui competência à União para "explorar, diretamente ou mediante autorização, concessão ou permissão (...) os serviços de radiodifusão sonora, e de sons e imagens".

Diferentemente da França, Itália e Inglaterra, essa exploração dos meios de recepção passiva da informação no Brasil é terceirizada politicamente à coletividade empresarial e exprime censurar positivamente ( $\operatorname{sim}-\operatorname{sim} \mathrm{V} \operatorname{sim} / n a \tilde{o}$ ) o oligopólio-quasemonopólio dos meios informativos, acatado nos seus próprios dialetos censórios. A nominal coletividade-estado Brasil, contudo, ao anunciar a "possibilidade de o governo criar uma rede pública de televisão, com conteúdo independente das influêncius politicas da vez" (Deak e Merli, 2007: 66), projeta efetivar a possibilidade constitucional (art. 223) de "complementar" "publicamente" essa heterocensura concentrada na "coletividade empresarial" ora simétrica, ora assimétrica nos interesses políticos com a nominal "coletividade-estado"

A terceirização política da heterocensura concentrada à coletividade empresarial no Brasil tem sido totalitariamente exercida com suporte na crença ciosa do monopólio da avaliação e crítica política pela "imprensa". signo ambíguo para os meios de recepção passiva (rádio e televisão) e os meios de recepção ativa (jornais, revistas. livros) da informação.

Conforme a tribo Civita (São Paulo), a "imprensa tem total liberdade para critic[ar a coletividade-estado](...). Ponto." (Marthe, 2007: 88) A avaliação das próprias políticas públicas, contudo. não caberia à coletividade-estado na sua interação e delegação da coletividade-família, tão pouco a esta: “O governo faz, a imprensu avaliu e o público julga"'.Nesse caso e por ato falho revelador da intermitência totalitáriocensória, "o público julga". mas por meio dos prévios "olhos e os ouvidos da imprensa" (2007: 88), expressão metonímica das tribos Marinho, no Rio de Janeiro, e Civita, em São Paulo, os "dois muiores grupos brasileiros de mídia" (Lima. 2006: 109), imprensa autoproclamada delegada - mas sem delegação da coletividade-família -, o Ministério da Verdade no Brasil.

Como se ubserva, a pretensão da coletividade-estado Brasil de complementur publicamente a heterocensura concentrada totalitariamente por tribos da região Rio-São-Paulo apenas indicia os contrastes censórios latentes e manifestos no mosaico censório intra-étnico entre mercado político e mercado econômico no território. 
Ressalvada essa possibilidade de clivagem censória com a criação de uma rede nacional de televisão estatal ainda não implementada, até aqui a lex constitucional tem expressado cotidianamente o monopólio da heterocensura concentrada no mando político da nominal coletividade-estado, terceirizando ao mando econômico mediante "autorização, concessão ou permissão" a expressão da exploração dessa censura sobre os meios de recepção passiva da informação, aqueles de mais alta freqüência de superposição política, o rádio (concessão por 10 anos), seguido da televisão (concessão por 15 anos). A freqüência dos receptores de rádio é de $98 \%$ nos domicílios brasileiros e de $83 \%$ nos veículos automotores em 2004; a freqüência de televisores é de $72,5 \%$ nos domicílios em 1989 (Mattos, 2005: 150-151; Deak e Merli, 2007: 68).

Ocorre observar que a exploração econômica por delegação contratual (concessão) (cotejar Mello Filho, 1984: 37) dos meios de informação passiva, rádio e televisão (cotejar Mattos, 2005: 152, 162; 38, 134-137, 154-156), é freqüentemente partilhada e instrumentaliza os interesses da exploração político-partidária (agenciamento dos parlamentares no mercado legislativo), dependente da publicidade da nominal coletividade-estado (mercado executivo), todos financiados compulsoriamente pela coletividade-família na forma da extorsão tolerável designada "tributo"

Nessa circunstância, como crer na imparcialidade do "jornalismo investigativo" quando se sabe, mediante números dissimulados para menos (Lima, 2006: 122; Deak e Merli, 2007: 66), que 10\% dos 513 deputados federais e entre 30 e $37 \%$ dos 81 senadores, diretamente ou mediante homens-de-palha, implicam concessionários dos meios de recepção passiva da informação (dados de 2005: Lima, 2006: 132, 135).

Além disso, como crer na idoneidade desses parlamentares, quando a Constituição Federal (art. 54, I, a) proibe a deputados e senadores "desde a expediçâo do diploma" "manter" anterior ou vir a "firmar" posterior "contrato com pessoa juridica de direito público, autarquia, empresa pública, sociedade de economia mista ou empresa concessionária de serviço público" caso do rádio e da televisão (CF, art. 21, XII, a).

Como crer, denotada a inidoneidade, no preparo intelectual para a delegação política de deputados como Jorginho Maluly (DEM-SP) e Carlos Alberto Leréia (PSDB-GO) que argumentam com o "direito adquirido" (Deak e Merli, 2007: 69), quando a Constituição proibe expressamente "manter" contrato anterior de serviço público?

Aperfeiçoando a proibição, a Constituição Federal (art. 55. I) imputa a deputados e senadores que "mantêm" contrato anterior, ou que "firmam" contrato 
posterior à diplomação a "perda do mandato" "por infringir" a "proibição estabelecida no artigo art. 54, I, $a$ "

Levantados por investigação os sorrateiros, e consultada a lista dos acintosos concessionários deputados e senadores da República, incluídos os expresidentes José Samey e Fernando Collor de Mello, a designada "bancada dos concessionários" do "coronelismo eletrônico" (Deak e Merli, 2007: 70, 66; Lima, 2006: 123142; Epcom, 2002: 18), o pesquisador terá os nomes e os índices parciais de intermitência da coletividade-bando Brasil nas heterocensuras dialetal e concentrada no território, aquela que instrumentaliza o rádio e a televisão para exercer o controle censório sobre o gado eleitor.

Um dos momentos históricos de superposição política da coletividadebando Brasil,quando o censor tem face e corpo conhecidos, ocorreu na intermitência minguante da superposição política do bando militar que dominou a terra brazilis de 1964 a 1985, e contou com a intermitência de coletividade-bando da Rede Globo de Televisão em simetria com a heterocensura concentrada extraordinariamente por mando coadjuvante do empresário das comunicações Roberto Marinho, que censurou o conteúdo da resistência ao conúbio militar-empresarial dominante, denotado e expresso pela coletividade-família por meio do "primeiro grande comicio da campanha das Diretas Já, a 25 de janeiro de 1984, na Praça da Sé, em São Paulo"

O evento implicava dois objetivos, o aniversário da cidade de São Paulo, e o ato de resistência da coletividade-família pedindo participação política no mando autocrata da nominal colctividade-estado e real coletividade-bando Brasil. ".....) Roberto [Marinho] não queria que se falasse no assunto informa Boni [José Bonifácio de Oliveira Sobrinho, então diretor da TV Globo]. O evento deveria ser transmitido sem nenhuma participação de qualquer um dos discursantes Preciso, o entrevistado esclarece: 'Quer dizer, a palavra, o que se dizia, o conteúdo estava censurado' (...) a ordem foi cumprida à risca". (Carta, 2006-375: 16; ver também Lima, 2006: 72-77) Reduziu-se a integridade do evento com seus dois objetivos tão só ao vídeo da tradição emocional do aniversário, censurando o áudio de urgência da lógica política da coletividade-família no seu pedido de liberdade.

Outro momento histórico - dentre os vários conhecidos deu-se em 2006, na superposição politica da coletividade-bando mediante a heterocensura concentrada extraordinariamente pela semiose jornalistica que pauta a nominal coletividade-estado Brasil, e também objetivou censurar a coletividade-família no território, às vésperas das eleições de primeiro de outubro do preposto presidente dessa coletividade. 
Tentou-se à época criminalizar nas eleições em São Paulo, território tribal dos Civita, Frias e Mesquita, a compra de informações relativas ao adversário pelo Partido dos Trabalhadores (PT), com a candidatura de Aloizio Mercadante, na disputa eleitoral com o Partido da Social DemocraciaBrasileira (PSDB), com a candidatura de José Serra (Aith, 2006: 48).

Tais informações - o dossiê - foram prontamente e em tempo recorde "investigadas" "verificadas" e "julgadas" todas "fajutas" pela tribo investigatória "imparcial" dos Civita (Martino e Joly, 2006: 74), que mediante slogans como "A luta continua" (Azevedo, 2006: 69), empenhou-se na formatação dos fatos para a indução do impeachment do candidato à eleição diversa, a de preposto da nominal coletividadeestado Brasil (Mainardi, 2006: 135).

Partindo desse episódio local, buscou-se censurar negativamente a preferência eleitoral nacional por $53 \%$ da coletividade-família no Brasil, aferida favoravelmente à reeleição de Luiz Inácio Lula da Silva (PT), e censurar positivamente os $35 \%$ de Geraldo Alckmin (PSDB) nas pesquisas (Coimbra, 2006-a: 14), e mediante a asserção autoral vinda da tribo dos Civita de o candidato Lula ter dado "Um tiro no pé às portas das eleições" como se deste partisse em Brasília a criminalizada compra de informações em São Paulo (Veja, 2006: 59).

Essa tentativa da coletividade-bando censória contou com a participação das tribos dos Frias e Mesquita, de São Paulo, e da tribo Marinho do Rio de Janeiro, por meio dos respectivos jornais Folha de S. Paulo e O Estado de S. Paulo de 30/09/2006, vésperas das eleições de $01 / 10 / 2006$. Na primeira página de ambos, uma foto superior $\mathrm{e}$ maior com a imagem impactante de I,168 milhão de reais ostensivamente identificáveis e 248.800 dólares em maços empilhados por 6 colunas, relativos àquela compra de informações, foi associada sintaticamente à foto inferior com a imagem desfavorável do candidato Lula. Esse candidato vestia um capuz escuro cobrindo parcialmente o rosto, enquadrado pela mão de um homem no seu ombro direito, tal qual se conduz um meliante sob custódia a uma delegacia de policia e depois de flagrado com o capuz próprio à ocultação da senda criminosa, avaliação induzida subliminarmente pela foto superior da página.

As respectivas matérias contavam, entre outras mentiras (Pereira, 2006), com a dissimulação de que as fotos do dinheiro foram feitas sub-repticiamente pelo delegado da Polícia Federal Edmilson Pereira Bruno, que integrado aos interesses políticos da coletividade-bando, manda: o "fato" "Tem de sair hoje [29/09/06, vésperas da eleição] à noite na tevê. Tem de sair no Jornal Nacional" da Rede Globo de Televisão 
(2006: 21), cujo noticiário nacional indicia $68 \%$ dos aparelhos de televisão ligados. segundo dados de 2004 (Lima, 2006: 147).

Conluiada à coletividade-bando, a Rede Globo de Televisão "omitiu informações cruciais na divulgação do dossiê [da compra de informações] e contrihuiu para levar a disputa ao $2^{\circ}$ turno [29/10]" das eleições da nominal coletividade-estado Brasil (Pereira, 2006: 20).

Para que se aquilate a manipulação censória e politicamente instrumentada aos interesses não públicos dessa coletividade-bando, naquele mesmo dia 29 de setembro, entre Manaus e Brasília, um Boeing com 154 passageiros da Gol chocou-se com um jato executivo Legacy da Embraer, caindo a seguir. A notícia das mortes repercutiu nacional e internacionalmente, contudo foi censurada pelo Jornal Nacional: "a tragédia do avião da (iol não entra; o noticiário eleitoral, com destaque para as fotos do dinheiro dos petistas, é praticamente o único assunto" (2006: 23).

A tentativa de criminalização de compra de informações, compra freqüente no mercado econômico e no mercado político e não proibida graficamente pelo mando nomogógico da coletividade-estado Brasil (Pereira, 2006: 26), integrou na coletividadebando a coadjuvância áulica do ministro Marco Aurélio de Mello.

Esse ministro do Supremo Tribunal Federal (STF), presidindo o Tribunal Superior Eleitoral (TSE), pautado pela censura dialetal da mídia, ao superpôr sua suposta e desejável imparcialidade como mediador interventivo profissional, agravou a censura, prejulgando fora dos autos e publicamente o fato politicamente adulterado, reforçando o impeachment pedido pela oposição do PSDB e PFL (Partido da Frente Liberal, hoje DEM - Democratas) e as tribos midiáticas (Linhares e Pereira, 2006: 81) ao sentenciar sem o due process of low: "É algo muito, muito pior que o Watergate" (Oltramari, 2006: 60; Linhares e Pereira, 2006: 81 e 80).

O ministro Marco Aurélio de Mello denotou subjetiva e objetivamente estar "interessado no julgamento da causa em favor de uma das partes" implicando-se em "fundada suspeição de parcialidade" contudo não se declarou suspeito pela censura negativa, conforme determina a Lei n. 5.869, de 11/01/73, indiciando no conjunto de ações c omissões despreparo para a função que exerce.

Esse integrante da nominal coletividade-estado Brasil, ao colocar em sintaxe um suposto fato cotidiano de compra de informações censuradas positivamente. em São Paulo, com a invasão, em Washington, da propriedade do Comitê Nacional do Partido Democrata dos Estados Unidos da América do Norte em 17/06/72, no episódio designado Watergate, e que desencadeou o pedido de impeachment do republicano Richard Milhous Nixon, forçando-o a renunciar em 1974 (Aith e Guandalini, 2006: 79), "colocou o presidente Lula, indiretamente, sob suspeita e comparável a Richard Nixon" 
"Marco Aurélio esqueceu-se não poder o juiz, fora do momento próprio, realizar" julgamentos "ou emitir juizo de valor sobre fatos que ainda vai apreciar" (Maierovitch, 2006: 18). A apuração judicial da possibilidade de abuso do poder econômico e político dessa suposta compra de informações, por insuficiência de provas, foi arquivada por votação unânime do TSE em 24/04/07. (Freitas, 2007: A5)

A despeito da censura negativa concentrada extraordinariamente nas tribos dos meios de comunicação da coletividade-bando acima pontuadas, a preferência eletiva não refluiu para o candidato subliminarmente indicado. implicando a vitória eleitoral de Luiz Inácio Lula da Silva no segundo turno (29/10) indiciada por $60,8 \%$, contra 39,2 de Geraldo Alkmin (Capital, 2006: 20).

O contraste da coletividade-familia com o não acatamento do candidato da coletividade-bando midiática acarretou a reiteração historicamente recorrente do povo "desprovido de razão" (Aristóteles, 1998-1260a5-7: 95), "inapto para governar por si" (Montesquieu, 1979: 32), "massa destituida de desenvolvimento para escolher" (Hitler, 1983: 64). Fernando Henrique Cardoso, correligionário de Geraldo Alkmin do PSDB, preposto da nominal coletividade-estado Brasil de 1995-2002, recalcou essa censura negativa aos $60,8 \%$ que votaram em Lula: “A midia (...) mostrou muita coisa. Só que, às vezes, a população não estú preparada para ouvir" (2006: 7).

Tal censura dialetal recorrente e desqualificadora_da coletividade-família, designada indistintamente "povo" (éthnos), "população" (conjunto quantificado) ou "massa" (quantum dinâmico). foi reiterada por essa coletividade-bando censória nas comunicações com suporte na crença da comunicação onipresente de sentido único e acato acrítico $\mathbf{E} \rightarrow \mathbf{R}$. Por essa expectativa, a "opinião pública" é necessariamente superposta pelos mais notáveis das elites econômica e política (Lima, 2006: 45), induzida por suas autoridades dialetais religiosas, educadoras e artísticas. alinhada e submissa pelas censuras negativa e positiva dos "sábios" nos meios de comunicação.

A emissão sígnica na comunicação. contudo, freqüentemente refrata $(\mathbf{E} \supset \mathbf{R})$, ou não é acatada. além de não implicar necessária recepção no desazo do possível receptor. Avaliados na credibilidade mediante pesquisa, Luiz Inácio Lula da Silva é mais confiável que a "imprensa" para $39 \%$ da coletividade-família (refratam), a "imprensa" é mais confiável para 35\% (acatam). com o desazo de 27\% dos entrevistados. (Dias, 2007: 39)

A crença de que a "opinião pública" .. designação problemática para dar sentido reificado a um casual agregado numérico da coletividade-família - pode ser conduzida por autoridades dialetais, ademais, tem suporte igualmente problemático na crença teorizada de que a participação política no ato de votar implica cálculo racional 
de "custo e beneficio" (Figueiredo, 1991: 204, 207), e nesse caso, caberia às autoridades dialetais dos meios de comunicação superpor o agregado da suposta virtude àquela "razão" do "povo", conformando-a censoriamente aos seus interesses políticos no mercado.

Ocorre pontuar que na coletividade-família os interpretantes emocionais precedem e dominam relativamente aos interpretantes lógicos (Modesto, 1999: 73-77). Conforme observado empírico-racionalmente por Charles Taber (Choi, 2007: 12), a tendência do eleitor é tomar decisões emocionais, e apenas no momento subseqüentejustificar racionalmente. Portanto, implica mera contingência e não automatismo o alinhamento censório entre a coletividade-família e as autoridades dialetais do mercado político.

Nos modos de produção sensu stricto não científicas da informação, freqüentes nos meios de comunicação por meio do conhecimento dialetal (Modesto, 2005-a: 372-373, 379-393), a sua qualidade é afetada pelas censuras negativa ou positiva que instrumentalizam os interesses políticos no mercado. Por carência de distância crítica, própria do conhecimento científico, as autoridades dialetais dos meios de comunicação acrescem à semiose jornalística verniz de racionalidade, e, como se observou nas eleições presidenciais de 2006, para confluir os votos ao candidato de sua escolha emocional mediante a formatação dos fatos políticos em versões verossímeis, no caso, criminalizando a compra de informação.

Esse acrescimento de "racionalidade" à precedente emocionalidade na produção da informação, não só pode implementar a venda de seu produto informativo, como agrega valor à suposta imparcialidade e objetividade de sua ação política, simulada por procedimentos investigatórios isentos.

Como se verifica, o mercado da informação implica um mosaico censório dinâmico e não linear, e a coletividade-família interage censoriamente, ora em simetria, ora assimetria com o mercado político. Nesse caso a coletividade-familia desacatou a heterocensura concentrada extraordinariamente no mercado de informação como carente de credibilidade (Carta, 2006-418: 14), censura travestida de informação pelos dialetos tribais, como indiciou a percepção pela Internet (Athayde, 2006), meio comunicativo acessado por $12,4 \%$ dos $16,6 \%$ domicílios com computador no território (Lima, 2006: 167) e onde dominam a censura difusa e a censura dialetal, mas até aqui resistente à censura concentrada.

"A vitória de Lula (...) revela quanto o nosso povo recusa a tutela daqueles que, até agora, gostavam de se considerar formadores de opinião", com seus dialetos dogmáticos: "a "classe média que forma opiniões" a "demora do grotão em 
alcançar a metrópole' 'a pedra que cai no lago e forma ondas que atingem primeiro a alguns e depois a todos" (Coimbra, 2006-b: 30,31), ou que "as opiniões se propagam do topo da sociedade para a base" (Feuerwerker, 2006: 58).

Como se obscrva ostensivamente, censurados negativamente pelo $\S 5^{\circ}$ do art. 220 da Constituição Federal (acima), contudo, a condição para o oligopólio-quasemonopólio do mercado econômico explorar dissimuladamente o mercado rádio-televisor da informação é acatar a heterocensura, ora dialetal, ora concentrada ordinária ou extraordinariamente no mercado político, de competência simulada da coletividadefamília, designada "povo" "soberano" e reificada na "União" (CF, art. 1 I, parágrafo único e art. 20).

A nominal coletividade-estado manda como real coletividade-bando pela longa manus do mercado, refluindo das assimetrias ("não/sim") com a mídia, para com esta realinhar-se censoriamente simétrica ("não-não") em intermitentes contrastes com a coletividade-família.

No mercado, osmeiosde recepção passiva da informação são explorados por oligopólio-quase-monopólio tribal dos meios de comunicação, caso das famílias Marinho (Globo) do Rio de Janeiro e Abravanel (SBT) de São Paulo, com rádio, TV, e afiliadas presentes em todos os Estados da federação e no Distrito Federal. Seguem-se no oligopólio, mas sem essa penetração, as famílias Macedo (Record) e Saad (Band) de São Paulo. (Epcom, 2002: 18)

O produto "democracia" implicando superposição política da coletividadefamília, se observado pela quantificação fenomenológica exposta nessa pesquisa, historicamente não tem integrado a agenda política bonobo (pacífica: Modesto, 2005-b: $573,575)$ das nominais coletividades-estado que intermitem no território brasileiro, como indicia a lex constitucional, cujo texto, além de exprimir propaganda enganosa, simula representar a coletividade-família mediante o monopólio da censura, coonestando e dissimulando as censuras dialetais tribais ou partidárias, ordinárias ou extraordinárias, concentradas pela lex e pelos meios informativos mediante o oligopólio-quasemonopólio dos meios de comunicação, a "Voz Oficiosa do Brasil"

3.2. Intermitências de coletividades-bando travestidas de coletividades-estado: indice de corrupção de uma etnia!

Além dessa intermitente superposição política da heterocensura concentrada fluida entre ordinária e extraordinária nos meios de comunicação pela semiose jornalística contrastando a coletividade-familia no território brasileiro, observa- 
se também a heterocensura concentrada extraordinariamente na superposição política da nominal coletividade-estado mediante o decreto do "estado de defesa" da Nomogogia de tipo lex constitucional brasileira. A fluidez censória entre as coletividades no território decai do contraste entre coletividade-família e expectada coletividade-estado, para implicar a superposição política da real coletividade-bando Brasil travestida de nominal coletividade-estado, conforme o diktat do "estado de defesa":

"Art. 136. O Presidente da República pode, ouvidos o Conselho da Republica e o Conselho de Defesa Nacional, decretar estado de defesa para preservar ou prontamente restabelecer, em locais restritos e determinados, a ordem pública ou a paz social ameaçadas por grave e iminente instabilidade institucional ou atingidas por calamidades de grandes proporçóes na natureza.

$\S I^{\circ} O$ decreto que instituir o estado de defesa determinará o tempo de suu duração, especificará us ureas a serem abrangidas e indicará, nos termos e limites da lei, as medidas coercitivas a vigorarem, dentre as seguintes:

I - restrições aos direitos de:

a) reunião, ainda que exercida no seio das ussociações;

b) sigilo de correspondência:

c) sigilo de comunicação telegráfica c telefônica.

(...)

$\S 2^{\circ}$ - O tempo de duração do estado de defesa não será superior a trinta dias, podendo ser prorrogado uma vez, por igual período, se persistirem as razões que justificaram a sua decretação"

Observamos nos mandos gráficos acima que o signo "censura" está dissimulado pelas referências tão só a seu objeto nas "restrições" implicativas de retenção do corpo excluído de "reunir-se" e aos "sigilos" implicativos de submissão de objetos textuais como "correspondência" e "comunicação telegráfica e telefônica" (ver item 1).

A superposição política da real coletividade-bando Brasil travestida de nominal coletividade-estado, por derradeiro, também observamos na heterocensura concentrada extraordinariamente na superposição política mediante o decreto do "estado de' sitio"

"Art. 137. O Presidente da República pode. ouvidos o Conselho da República e o Conselho de Defesa Nacional. solicitar ao Congresso Nacional autorização para decretar o estado de sitio nos casos de:

I - comoção grave de repercussão nacional ou ocorríncia de fatos que comprovem a ineficácia de medida toinada durante o estado de defesa;

II - declaração de estado de guerra ou respostu a agressão 
armada estrungeira.

Parágrafo único. O Presidente da República, ao solicitar autorização para decretar o estado de sítio ou sua prorrogação, relatará os motivos determinantes do pedido, devendo o Congresso Nacional decidir por muioria absoluta.

Art. 138. O decreto do estado de sítio indicará sua duração, as normas necessárias a sua execução e as garantias constitucionais que ficarão suspensas, e, depois de publicado, o Presidente da República designará o executor das medidas especificas e as áreas abrangidas.

$\S 1^{\circ} O$ estado de sífio, no caso do art. 137, I, não poderá ser decretado por mais de trinta dias, nem prorrogado, de cada vez, por prazo superior; no do inciso II, poderá ser decrelado por todo o tempo que perdurar a guerra ou a agressão armada estrangeira. $\$ 2^{\circ}$ Solicitada autorização para decretar o estado de sitio durante o recesso parlamentar, o Presidente do Senado Federal, de imediato, convocará extraordinariamente o Congresso Nacional para se reunir dentro de cinco dias, a fim de apreciar o alo.

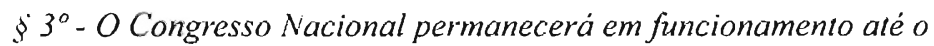
término das medidas coercitivas.

Art. 139. Na vigência do estado de sitio decretado com fundamento no art. 137, I, só poderão ser tomadas contra as pessoas as seguintes medidas:

I - obrigação de permanência em localidade determinada;

II - detenção i'm edificio não destinado a acusados ou condenados por crimes comuns;

III restrições relativas à inviolabilidade da correspondência, ao sigilo das comunicações, à prestação de informações e à liberdade de imprensu, rudiodifusão e televisão, na forma da lei;

IV suspensão da liberdade de reunião;

$V$ - busca e apreensão ern domicilio;

$V I$ - intervenção nas empresas de serviços públicos;

(...)

Parágrafo único. Não se inclui nas restrições do inciso III a difusão de pronunciamentos de parlamentures efetuados em suas Casas Legislativas, desde que libcrada pela respectiva Mesa".

Nesses dispositivos relativos ao "estado de sítio" o signo "censura" igualmente permanece dissimulado pelas referências apenas a seu objeto nas "medidas" implicativas de retenção do corpo obrigado à "permanência em localidade determinada" "detido em edifício não carcerário", "impedido de reunir-se" e às "restrições" implicativas de submissão de objetos textuais de "correspondência", "comunicações" "prestação de informações" "liberdade de imprensa, radiodifusão e televisão" "busca e apreensão em domicilio" censura administrativa mediante "intervenção nas empresas de serviços públicos" além da sugestão de autocensura ou 
heterocensura aos "pronunciamentos de parlamentares efetuados em suas Casas Legislativas", i.e., "desde que liberada [a difusão dos pronunciamentos] pela respectiva Mesa"

A doutrina legista é condescendente com a superposição política da coletividade-bando Brasil travestida de coletividade-estado. Só de passagem (Silva, 2005: 762) reconhece que o edifício censório da lex constitucional de hoje aperfeiçoou ao nível do escamoteio de Hermes a dominância em terra brazilis do mando censório de coletividades-bando tribais autoreferidas na abstração asséptica do signo por "República Federativa do Brasil" no decorrer da história brasileira.

Nos dispositivos apontados (Silva, 2005: 769), a hermenêutica acata sem reconhecer a existência da censura superposta, designando eufemística e abundantemente os decretos censórios do "estado de defesa" e do "estado de sítio" dissimulados nos topoi koinoi (lugares comuns) reiterativos de "legalidade extraordinária" (2005: 761, 762, 763, 768, 769, 770), "legalidade especial" (2005: 765), "legalidade de exceção" (2005: 766), ou de "normatividade extraordinária" (2005: 767).

Há até mesmo o caso de um texto empresarial que sequer ressalva tais dispositivos implicarem censura, signo mencionado uma única vez nos comentários à nomogogia acima e de maneira indireta, por reprodução de artigo da "constituição de 1967' (sic) (Price Waterhouse, 1989: 606), exemplar manifesto de censura dialetal e cooptável (ver subitem 1.1, fig. 3).

Correspondendo censoriamente por "sim-sim" ou "não-não" da autocensura cotidiana do corpo pessoal, para as assimetrias da heterocensura "sim/não" da censura difusa, ou "não/sim" da censura dialetal na multiplicidade dos papéis do corpo no espaço doméstico ou no espaço público, do mercado econômico ao mercado político, a fluidez das simetrias e assimetrias dialetais e concentradas reflui da intermitência da heterocensura concentrada ordinariamente para a dominância invasiva e assimétrica da heterocensura concentrada extraordinariamente.

A relação de simetria entre a coletividade-família e a real coletividadeestado rompe-se ao reduzir essa diversidade censória "sim-sim" "não-não" "sim/não", "não/sim" para a superveniente aglutinação diádica censória "não/sim" do "mando/desacato" macrocoletivamente confrontados no território étnico.

O fato de a ruptura da simetria estar prevista na lex grafada para coonestar a censura não implica expectativa mnemômica correspondente do subposto corpo do suposto cidadão, singularmente nos momentos de conflito em que os neurônios são 
fisicamente e dominantemente esculpidos por hormônios do stress emocional, implicando escassa racionalidade.

Acuados pela nomogógica censura negativa fluindo entre a expropriação da informação e, ou, do agir dinâmico do corpo (4ª classe sígnica Peirce, 1978-2.257: 147), refluem os interpretantes lógicos do agir legisígnico dominantemente triádico da reflexão $\left(6^{3}\right.$ classe - 1978-2.259: 147-148) para os interpretantes energéticos (amígdala) dos mecanismos neurológicos diádicos de fuga ou luta e para os interpretantes emocionais (hipocampo) (Modesto, 1999; Hülshoff, 2007: 14; Teicher, 2002: 54-57, 61).

Na singularidade animal entre a fuga e a luta, a tropia é pela liberdade do corpo e da memória externa dos objetos textuais informativos, dos singulares pessoais à máxima disponibilidade da semiose jornalística crível, com repulsão para a invasividade do mando censor, daí a conseqüente ruptura nomogógica com a nominal coletividade-estado, real coletividade-bando pelo mando censor invasivo extraordinário. Implica mera fição a pretensão expressa no "estado de defesa" (art. 136) e no "estado de sítio" (art. 137 a 139) da nomogogia da espécie constituição federal brasileira possibilitar mando crivel nessas superposições políticas próprias de uma coletividade-bando.

Além dos dispositivos censórios observados em relação à realidade, a própria lex constitucional implementa essa ruptura entre coletividade-família e coletividade-estado noutro dispositivo, acentuando a assimetria entre as macrocoletividades em conflito e favorecendo a nominal coletividade-estado censora, decaindo esta coletividade da reivindicação de "representação" política, já precária ordinariamente por implicar no cotidiano "delegação" política, uma vez que não há correspondência biunívoca entre a nomopoese e os interesses quantificados da cidadania nas democracias indiretas para implicar representação, caso do Brasil.

O dispositivo suplementar dessa ruptura é a reivindicada "isonomia" pela qual "Todos são iguais perante a lei, sem distinção de qualquer natureza" (CF, art. $5^{\circ}$ ). Com a heterocensura concentrada e a superposição política da nominal coletividadeestado por meio da "distinção" de "natureza" censória, também se rompe tal expectativa de "igualdade" censória com a coletividade-família, como visto no subitem 3.1 com a heterocensura concentrada ordinariamente e aqui com a heterocensura concentrada extraordinariamente.

Nesse contraste por mando convertido em conflito por força entre macrocoletividades e respectivas expectativas e corpos, a então referida coletividadeestado perde com a censura sua qualidade de delegada da coletividade-família e aprofunda a nascente carência de simetria advinda da desigualdade no acesso ao corpo e aos objetos textuais informativos, deformando sobremaneira a relação entre 
coletividade-família e coletividade-estado, para implicar a coletividade-familia em assimetria com a nominal coletividade-estado e real coletividade-bando.

A nominal coletividade-estado decai de seu real e frágil mando delegado, simulando "representação" política, para assimetricamente por mando ou por força contrastar ou conflitar com a coletividade-família, características físico-semióticas de uma coletividade-bando.

Os motivos e justificações dessa nominal coletividade-estado, nessa contingência censória de bando, a teoria política designa "razão de estado" pela qual "afirma que a segurança do Estado é uma exigência de tal importância que os governantes, para a garantir, são obrigados a violar normas jurídicas [no caso das espécies nomogógicas latinas], morais, políticas e econômicas que consideram imperativas, quando essa necessidade não corre perigo" (Pistone, 1986: 1.066).

Em nome da "segurança" própria de parte, desconsiderado o todo continente da coletividade étnica, a nominal coletividade-estado desqualifica a coletividade-família mediante a censura concentrada extraordinariamente, rompendo a simetria condicional e indeterminada da delegação política do mando, implicando real coletividade-bando em assimetria nomogógica evidenciada pela assimetria censória concentrada.

Tanto nos casos da censura concentrada ordinariamente nos meios de recepção passiva da informação, rádio e televisão, nos meios de recepção ativa da informação, jornais, revistas, livros, quanto nos casos da censura concentrada extraordinariamente, v.g., o Jornalista, o Editor do Jomal, da Revista ou do Livro, o Diretor de Televisão, o Porteiro do Cinema, o Juiz da Comarca, o Diretor do Departamento de Justiça, Classificação, Títulos e Qualificação, o Presidente do Tribunal Superior Eleitoral, ou o Presidente da República são as faces visíveis da coletividadebando Brasil brandindo as mãos ou o verbo censório da "razão de bando" simulando ora "razão de empresa" ora "razão de estado"

Cabe considerar que nas intermitências dessas superposições políticas da censura concentrada extraordinariamente, por contingência contrastiva ou conflitiva e assimetria, qualquer expressãonominal "razão de empresa" ou "razão de estado" decai para denotar real "razão de bando"

Assim, violar qualquer espécie de mando nomogógico que suporta a simetria por delegação ou representação política da coletividade-família pela nominal e real coletividade-estado, denota retirado o suporte sígnico da delegação ou representação que exprimiria uma real coletividade-estado, sobejando a relação decaída na assimetria entre uma coletividade-família e uma real coletividade-bando. Nota-se aqui, en passant, 
que mesmo a reivindicação doutrinária de "razão de estado" ao fundar-se numa assimetria mais denota e exprime uma tautologia, referindo um interpretante emocional mediante "slogan de razão" do próprio bando.

Como se observa, as relações interpessoais suportam a autocensura e a heterocensura, esta enquanto difusa ou dialetal, quando a disseminação da ambivalência censória implica a sobrevivência do corpo, mas não suportam que a sobrevivência do continente coletivo etnicamente considerado seja ameaçada nos mecanismos de fuga ou luta, por retenção do corpo ou submissão de objetos textuais informativos, mediante a heterocensura concentrada extraordinariamente implicativa de razão da coletividadebando.

Nesses casos dilemáticos entre Éros e Thánatos, a resposta freqüente da coletividade-familia à coletividade-empresa e à nominal coletividade-estado, quando reais coletividades-bando, não é pela força, mas pelo mando da corrupção vital. As freqüências censórias de assimetria entre coletividades-família e nominais coletividades-estado, tanto em relação à retenção de uma conduta do corpo, quanto na submissão de objetos textuais informativos, ou de objetos do consumo cotidiano ou extracotidiano demandados pela coletividade-família, se quantificadas, implicam o índice da corrupção letal de uma etnia.

São Paulo, setembro de 2006.

\section{Referências}

ABNT, Associação Brasileira de Normas Técnicas. Informação e documentação. Referências. Elaboração. NBR 6023. Agosto. Rio de Janeiro: ABNT, Associação Brasileira de Normas Técnicas, 2002.

AITH, Marcio; GUANDALINI, Giuliano. A PF finge que investiga ... Em Veja. Edição 1.975. 27/09/06. P. 76-79. São Paulo: Editora Abril, 2006.

AITH, Marcio. Um enigma chamado Freud. Em Veja. Edição 1.978. 18/10/06. P. 44-51. São Paulo: Editora Abril, 2006.

ATHAYDE, Phydia de. As reações desiguais. Em Carla Capital. Seu país. Edição 416. P. 29-31. 25/10/06. São Paulo: Editora Confiança, 2006.

ARAUJO, Paulo Cesar de. "Estão fazendo censura prévia". Entrevista a Eliane Lobato. Em Istoé. P. 7-9. N. 1.958. 09/05/07. São Paulo: Editora Três, 2007.

ARISTÓTFLES. Politica. Edição bilingüe. Traduzido do grego por António Campelo Amaral e Carlos de Carvalho Gomes. Coleçãa: Vega Universidade / Ciências Sociais e Políticas. Lisboa: Veja, 
1998.

AZEVEDO, Reinaldo. Uma não é tribunal. Não absolve ninguém.. Em Veja. Artigo. Edição 1.972. 06/09/06. P. 68-69. São Paulo: Editora Abril, 2006.

BASTOS, Celso Ribeiro. Comentários à Constituição do Brasil: promulgada em 5 de outubro de 1988. Volume 2. Arts. $5^{\circ}$ a 17. Em Comentários à Constituiçâao do Brasil: promulgada em 5 de outubro de 1988. Celso Ribeiro Bastos e Ives Gandra Martins. São Paulo: Saraiva, 1989.

BOFF, Leonardo. Igreja: carisma e poder - ensaios de eclesiologia militante. Inclui apêndice com os documentos do processo doutrinário movido pelo Vaticano contra o Autor. Série Religião e Cidadania. São Paulo: Editora Ática, 1994.

BOHR, Niels. Física atômica e conhecimento humano ensaios 1932-1957. Traduzido por Vera Ribeiro. Revisão técnica pelo físico Ildeu de Castro Moreira. Rio de Janeiro: Contraponto, 1995.

BRASIL. Decreto-lei 891, de 25/11/1938. Aprova a Lei de Fiscalização de Entorpecentes. Em Tóxicos. P. 15-34. São Paulo: Saraiva, 1994.

BRASIL. Constituição da República Federativa do Brasil de 1988. Em 12/06/02. Brasília: <http://www.planalto.gov.br/ccivil_03/Constituição/Constituição.htm>, 2002.

BRASIL. Lei 8.069, de 13/07/1990. Dispõe sobre o Estatuto da Criança e do Adolescente e dá outras providências. Em Estatuto da Criança e do Adolescente. P. 1-55. São Paulo: Saraiva, 1990.

BRASIL. Lei 8.078, de 11/09/1990. Dispõe sobre a proteção do consumidor e dá outras providências. Em Código de Proteção e Defesa do Consumidor. P. 1-31. São Paulo: Saraiva, 1991.

BRASIL. Lei 9.610, de 19/02/1998. Altera, atualiza e consolida a legislação sobre direitos autorais e dá outras providências. Em Código de Direitos Autorais e Acordos Internacionais. Eduardo Salles Pimenta. P. 17-297. São Paulo: LEJUS, 1998.

BRASIL. Portaria 264, de 09/02/2007, do Ministério da Justiça. Em 26/03/07. Brasília: $<$ http://www.mj.gov.br/classificacao/legislacao/2007portaria264.pdf>, 2007-a.

BRASIL. Portaria 1.220, de 11/07/2007, do Ministério da Justiça. Em 12/07/07 Brasília: < http://www.mj.gov.br/classificacao/legislacao/2007portaria 1220.pdf>, 2007-b.

BRITANNICA, Encyclopædia. Benedict XVI, or Joseph Alois Ratzinger (pope). Em 09/05/07. <http://www.britannica.com/eb/topic-676944/Benedict-XVI>. 2007.

CAHILL, Larry. A arquitetura da diversidade. Em Viver Mente \& Cérebro. Scientific American. Edição especial. N. 10. Junho. P. 42-49. São Paulo: Duetto Editorial. 2007. 
CAPITAL, Carta. Revista. O povo não crê em bruxas. Em Carıa Capital. Seu país. Edição 417. P. 20-22. 01/11/06. São Paulo: Editora Confiança, 2006.

CARDOSO, Fernando Henrique. Entrevista circunstancial. Herói da democracia. André Siqueira. Em Carta Capital. Brasiliana. Edição 418. P. 06-07. 08/11/06. São Paulo: Editora Confiança, 2006.

CARTA, Mino. Prepotência e corrupção. Em Carta Capiral. A Semana. Edição 375. P. 16-17. 11/01/06. São Paulo: Editora Confiança, 2006-375.

CARTA, Mino. A opinião pública derrota a mídia. Em Carta Capital. A Semana. Edição 4I8. P. 14. 08/11/06. São Paulo: Editora Confiança. 2006-418.

CARTA, Mino. Hipocrisia, arrogância. E o Q.I.? Em Carta Capital. A Semana. Edição 458. P. 1415. 22/08/07. São Paulo: Editora Confiança, 2007-458.

CHOI, Charles Q. Voto com o coração: nas urnas, a emoção prevalece sobre a razão. Em Scientific American Brasil. Janeiro. N. 56. P. 12. São Paulo: Ediouro, Segmento-Duetto Editorial, 2007.

COIMBRA, Marcos. Pesquisas e votos. Em Carıa Capital. Edição extra. Edição 416-A. P. 14-15. 27/10/06. São Paulo: Editora Confiança, 2006-a.

COIMBRA, Marcos. Uma bonita vitória. Em Carla Capital. Edição extra. Edição 418. P. 30-31. 09/1 1/06. São Paulo: Editora Confiança, 2006-b.

COSTAS, Ruth (2007). Cháves busca monopolizar mídia. Em O Estado de São Paulo. Internacional. 03/06/07. P. A20-21. São Paulo: O Estado de São Paulo.

DEAK, André; MERLI, Daniel. Coronelismo eletrônico. Em Rolling Stone. Política nacional. Edição 7. Abril. P. 66-70. São Paulo: Spring Publicações. 2007.

DIAS, Maurício. A armadura do presidente. Em Carta Capital. Seu pais. Edição 454. P. 38-41. 25/07/07. São Paulo: Editora Confiança, 2007.

DUFFY, Eamon. Santos e pecadores: história dos papas. Traduzido do inglês por Luiz. Antônio Araújo. São Paulo: Cosac \& Naify, 1998.

DURANT, Will. A idade da fé. Em A História da civilização. Traduzido por Mamede de Souza Freitas. V. IV. Rio de Janeiro: Editora Record, 1971.

EPCOM, Instituto de Estudos e Pesquisas em Comunicação. Quem são os donos. Em Carla Capital. Especial - televisão. Fdição 179. P. 17-19. 06/03/02. São Paulo: Editora Confiança, 2002. FRTHAL, João Marcello. Os riscos da omissão. Em Carta Capital. Seu país. Edição 453. P22-26. 
18/07/07. São Paulo: Editora Confiança, 2007.

FARIA, Anacleto de Oliveira. Poder de Polícia I. Em Enciclopédia Saraiva do Direito. V. 59. P. 81-85. São Paulo: Saraiva, 1981.

FEUERWERKER, Alon. Por que Lula ganhou. Em Rolling Stone. Política nacional. Edição 2. Novembro. P. 58-59. São Paulo: Spring Publicações, 2006.

FIGUEIREDO, Marcus. A decisão do voto: democracia e racionalidade. São Paulo: Editora Sumaré, ANPOCS, 1991.

FREITAS. Silvana de. TSE arquiva investigação contra Lula no caso do dossiê antitucano. Em Folha de São Paulo. Brasil. P. A5. 25/04/07. São Paulo: Empresa Folha da Manhã, 2007.

FREUD, Sigmund. Lecciones introductorias al psicoanalisis. Los sueños. La censura del sueño. Em Obras completas. Tomo II. P. 2.203-2.211. Traduccion directa del aleman por Luis LopezBallesteros y de Torres. Madrid: Biblioteca Nueva, 1981-97.2.9.

GILISSEN, John. Introdução histórica ao direito. Traduzido do francês por A. M. Hespanha e L. M. Macaísta Malheiros. Lisboa: Fundação Calouste Gulbenkian, 1995.

GRAIEB, Carlos. Nem política, nem espetáculo. Em Veja. Especial. Edição 1.902. 27/04/05. P. 8486. São Paulo: Editora Abril, 2005.

GUIMARÃES, Maria. De servo a senhor. Em Pesquisa Fapesp. Genética. N. 133. Março. P. 4851. São Paulo: Fundação de Amparo à Pesquisa do Estado de São Paulo - FAPESP, 2007.

HEIN, Avi. Hitler Youth. Em Jewish Virtual Lihrary. Em 09/05/07<http://www.jewishvirtuallibrary.org/jsource/Holocaust/hitleryouth.html>, 2007.

HEISENBERG, Werner. Physics and Philosophy. Introduction by Paul Davies. London: Penguin, 1989.

HITLER, Adolf. Minha luta. Traduzido do alemão. São Paulo: Editora Moraes, 1983.

HOUAISS, Antônio. CD-ROM. Dicionário eletrônico Houaiss da lingua portuguesa. Rio de Janeiro: Instituto Antônio Houaiss - Editora Objetiva, 2001.

HÜLSHOFF, Thomas. Loucos de raiva. Em Viver Mente \& Cérebro. Scientific American. N. 9. Março, 2007. P. 12-17. São Paulo: Duetto Editorial, 2007.

ISTOÉ. CD-ROM. 1920 A lei seca nos Estados Unidos. Fm Enciclopedia digital Istoé Século XX. V. 3. 1920-1929. Barcelona: Plaza \& Janés Editores; São Paulo: Grupo de Comunicação Três, 1998-3. 
ISTOÉ. CD-ROM. Fim da Lei Seca nos EUA. Em Enciclopedia digital Istoé Século XX. V. 4. 1930-1939. Barcelona: Plaza \& Janés Editores; São Paulo: Grupo de Comunicação Três, 1998-4.

KAMEL, Ali (2007). A grande imprensa. Em O Globo. De 07/08/07. Em 21/08/07. Rio de Janeiro: $<$ http://clipping.planejamento.gov.br/Noticias.asp?NOTCod =373175>.

KERR, K. Austin. American dream. Em New Scientist. End of the millenium special edition. Alcohol: the inside story. November 27. P. 94-95. London: New Science, 1999.

KRIEGER, Gustavo. Quem Indica. Em Rolling Stone. Política nacional. Edição 6. Março. P. 4043. São Paulo: Spring Publicações, 2007.

LAO TZY. Tao Te Ching Pai Hua Chu Chie [Tao Te Ching explicado e comentado em linguagem acessivel]. Edição em chinês da xilogravura conservada no honorável palácio chinês de Shang Hai (Shang Hai Pan). Texto intercalado por explicação e comentário do mestre Han Shan. P. 23-115. Shang Hai e T'ai Pei: San Yang, s.d.

LAO TZY. 道 [Tao]. Reversão chinês-português por 李 斯 默 (Luiz Sergio Modesto). São Paulo: Sibila Edicção, Inédito.

LAROUSSE. Justiniano I (Flavius Petrus Sabbatius Justinianus). Em Grande Enciclopédia Larousse Cultural. V. I4. P. 3.388. São Paulo: Nova Cultural, 1995.

LAU, Nelson C.; BARTEL, David P. Censores do genoma. Em Scientific American Brasil. Setembro. N. 16. P. 50-57. São Paulo: Ediouro, Segmento-Duetto Editorial, 2003.

LEGENDRE, Pierre. O amor do censor - ensaio sobre a ordem dogmática. Traduzido por Aluísio Pereira de Menezes, M. D. Magno, e Potiguara Mendes da Silveira Júnior, do Colégio Freudiano do Rio de Janeiro. Rio de Janeiro: Forense Universitária e Colégio Freudiano, 1983.

LEUZINGER-BOHLEBER, Marianne. Função onírica. Em Viver Mente \& Cérebro. Scientific American. N. 159. Abril. P. 48. São Paulo: Duetto Editorial, 2006.

LIMA, Venício A. de. Midia: crise política e poder no Brasil. São Paulo: Editora Fundação Perseu Ábramo, 2006.

LINCOLN, The New Lincoln Library Encyclopedia. Political terms and institutions. In The Lincoln Library of essential information. V. 1. P. 805-832. Columbus: The Frontier Press Company, 1978-1.

LINCOLN, The New Lincoln Library Encyclopedia. Biography. In The Lincoln Library of essential information. V. 2. P. 1831-2144. Columbus: The Frontier Press Company, 1978-2.

LINHARFS, Juliana; PEREIRA, Camila. "Pior do que o Watergate". Em Veja. Edição 1.975. 
27/09/06. P. 80-82. São Paulo: Editora Abril, 2006.

MAIEROVITCH, Wálter Fanganiello. Garantias eleitorais. Em Carta Capital. Linha de frente. Edição 417. 01/1।/06. P. 18. São Paulo: Editora Confiança, 2006.

MAINARDI, Diogo. Umm golpista sem farda. Em Veja. Artigo. Edição 1.976. 04/10/06. P. 137. São Paulo: Editora Abril, 2006.

MARTHE, Marcelo. Com a faca e o queijo. Em Veja. Imprensa. Edição 2.000. 21/03/07. P. 88-89. São Paulo: Editora Abril, 2007.

MARTINO, Victor; JOLY, Heloisa. Um bode expiatório Em Veja. Edição 1.975. 27/09/06. P. 74. São Paulo: Editora Abril, 2006.

MATTAR, João. Metodologia científica na era da informática. São Paulo: Saraiva, 2005.

MATTOS, Sérgio. Midia controlada: a história da censura no Brasil e no mundo. São Paulo: Paulus, 2005.

MEllo fILHO, José Celso de. Constituição Federal anotada [1967]. São Paulo: Saraiva, 1984.

MODESTO, Luiz Sergio. As drogas do estado. Tese multidisciplinar fundamentada no paradigma metadisciplinar da Semioselogia apresentada perante a Faculdade de Direito da Universidade de São Paulo USP : e defendida em 30/06/95. para obtenção do título de Doutor em Direito do Fstado (Política). São Paulo: Sibila Edicção, 1994.

MODESTO, Luiz Sergio. Escusa de consciência - delito travestido de Direito. Tese - atualização fundamentada no paradigma metadisciplinar da Semioselogia apresentada perante a Faculdade de Direito da Universidade de São Paulo - USP -. e defendida em 13/11/89 para obtenção do título de Mestre em Direito Constitucional (Direito do Estado). São Paulo: Sibila Edicção,1996.

MODESTO, Luiz Sergio. Arquétrio Fratura Colateral da Cultura. Tese multidisciplinar fundamentada no paradigma metadisciplinar da Semioselogia apresentada perante o Programa de Estudos Pós-Graduados em Comunicação e Semiótica da Pontificia Universidade Católica de São Paulo - PUC-SP -, e defendida em 21/09/99, para obtenção do título de Doutor em Comunicação e Semiótica, em Curso de Pós-doutorado. São Paulo: Sibila Edicção, 1999.

MODESTO, Luiz Sergio. Sofisma de "globalização" em mercado mundial entrópico. Em Revista da Faculdade de Dircito - Universidade de São Paulo. P. 509-534. V. 98, janeiro/dezembro, 2003. ISSN 0303-9838. São Paulo: Universidade de São Paulo, Faculdade de Direito. Serviço Técnico de Imprensa, 2003.

MODESTO, Luiz Sergio. Conhecimentos trivial, dialetal e científico Argumento nomogógico e 
argumento cientifico. Em Revista da Faculdade de Direito - Universidade de São Paulo. P. 361428. V. 100, 2005, janeiro/dezembro. ISSN 0303-9838. São Paulo: Universidade de São Paulo, Faculdade de Direito, Serviço Técnico de Imprensa, 2005-a.

MODESTO, Luiz Sergio. Civilidade Verbete. Em Revista Brasileira de Direito Constitucional RBDC. P. 571-576. V. 6, julho/dezembro. ISSN 1678-9547. São Paulo: Escola Superior de Direito Constitucional, 2005-b.

MONTESQUIEU, Charles Louis de Secondat, baron de la Brède et de. Do espirito das leis. Em Montesquieu, os pensadores. Traduzido por Fernando Henrique Cardoso e Leôncio Martins Rodrigues. São Paulo: Editora Abril, 1979.

OLTRAMARI, Alexandre. O vôo cego do petismo. Em Veja. Edição 1.975. 27/09/06. P. 60-66. São Paulo: Editora Abril, 2006.

PAUlO, Folha de São. Os EUA e a guerra. Em Folha de São Paulo. Mundo. P. A 16. 16/04/03. São Paulo: Empresa Folha da Manhã, 2003.

PEIRCE, Charles Sanders. Pragmatism and pragmaticism. In Collected Pupers of Charles Sanders Peirce. V. V. Cambridge: The Belknap Press of Harvard University Press, 1974-5.

PEIRCE, Charles Sanders. Scientific metaphysics. In Collected Papers of Charles Sanders Peirce. V. VI. Cambridge: The Belknap Press of Harvard University Press, 1974-6.

PEIRCE, Charles Sanders. Principles of philosophy. In Collected Papers of Charles Sanders Peirce. V. I. Cambridge: The Belknap Press of Harvard University Press, 1978-1.

PEIRCE, Charles Sanders. Elements of logic. In Collected Papers of Charles Sanders Peirce. V. II. Cambridge: The Belknap Press of Harvard University Press, 1978-2.

PEREIRA, Raimundo Rodrigues. Os fatos ocultos. Em Carta Capital. Seu país. Edição 415. 18/10/06. P. 20-26. São Paulo: Editora Confiança, 2006.

PETRY, André. A burrice do rei. Em Veja. Edição 2.007. 09/05/07. P. 53. São Paulo: Editora Abril, 2007.

PIAGET, Jean. A formação do simbolo na criança imilação, jogo e sonho, imagem $e$ representação. Traduzido por Álvaro Cabral e por Christiano Monteiro Oiticica. Rio de Janeiro: Guanabara, Koogan, 1978.

PIERRARD. Pierre. História da Igreja. Traduzido do francês por Álvaro Cunha. São Paulo: Edições Paulinas, 1982.

PISTONE, Swergio. Razão de Estado. Em Dicionário de política. Norberto Bobbio. Nicola 
Matteucci e Gianfranco Pasquino. Traduzido por João Ferreira, Luís Guerreiro Pinto Cacais, Gaetano Lo Mônaco, Renzo Dini e Carmen C. Varrialle. P. 1.066-1.073. Brasília: Editora Universidade de Brasília, 1986.

PRICE WATERHOUSE. A Constituição do Brasil 1988 comparada com a Constituição de $1967 e$ comentada. São Paulo: Price Waterhouse, 1989.

RANDOM HOUSE Unabridged Dictionary. CD-ROM. The Random House Dicionary of the English Language. Orem: Novell Applications Group, 1994.

RIBEIRO, Sidarta. Mais vivo que nunca. Em Viver Mente \& Cérebro. Scientific American. Limiar Neurociência. N. 164. Setembro. P. 23. São Paulo: Duetto Editorial, 2006.

RIDLEY, Matt. As origens da virlude - um estudo biológico da solidariedade. Traduzido por Berilo Vargas. São Paulo: Editora Record, 2000.

SABINO, Mario. Continuar para mudar. Em Veja. Especial. Edição 1.902. 27/04/05. P. 64-71. São Paulo: Editora Abril, 2005.

SILVA. José Afonso da. Curso de direito constitucional positivo. São Paulo: Editora Revista dos Tribunais. 2005.

SMITH, David Livingstone. Mentirosos inatos. Em Viver Mente \& Cérebro. Scientific American. N. I 53. Outubro. P. 30-37. São Paulo: Duetto Editorial, 2005.

SOLMS, Mark. A interpretação dos sonhos e as neurociências. Em Viver Mente \& Cérebro. Scientific American. N. 150. Julho. P. 28-36. São Paulo: Duetto Editorial, 2005.

SOLMS, Mark. O encontro bem-sucedido de olhares distintos. Entrevista a Steve Ayan. Em Viver Mente \& Cérebro. Scientific American. N. 159. Abril. P. 45-47. São Paulo: Duetto Editorial. 2006.

STENGERS, Isabelle; RALET, Olivier. Drogues le défi hollandais. Collection Les Empêcheurs de Penser en Rond. Paris: Laboratoires Delagrange, 1991.

TEICHER. Martin H. Scars that won't heal: the neurobiology of child abuse. In Scientific American. March. V. 286. N. 3. P. 54-61. New York: Scientific American, 2002.

TEIXEIRA, Jerônimo. A fogueira de Roberto Carlos. Em Veja. Justiça. Edição 2.007. 09/05/07. P. 120-121. São Paulo: Editora Abril, 2007.

TEIXEIRA, Duda (2007). Viva o movimento estudantil ... da Venezuela. Em Veja. Intcrnacional. Edição 2.011. P. 72-73. 06/06/07. São Paulo: Editora Abril.

VALLADARES, Ricardo. Um perigoso Пlerte com a censura. Em Veja. Cultura. Fdição 1.936. 
21/12/05. P. 150-153. São Paulo: Editora Abril, 2005.

VATICANO. Biografia de sua santidade Bento XVI. Libreria Editrice Vaticana. Em 09/05/07.

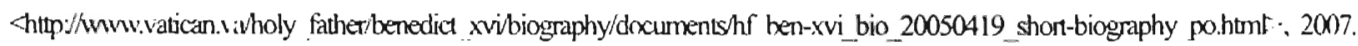

VEJA. Revista. Essa é de doer. Fm Veja. Educação. Edição 1.673. 01/11/00. P. 94. São Paulo: Editora Abril, 2000.

VEJA. Revista. Lim tiro no pé às portas da eleição. Frm Veja. Fdição 1.975. 27/09/06. P. 58-59. São Paulo: Editora Abril, 2006.

VEJA. Revista. Nada a ver com censura. Em Veja. Sociedade. Edição 1.996. 21/02/07. P. 75. São Paulo: Editora Abril. 2007-1996.

VEJA. Revista. A nova imagem de Delúbio [Delúbio Soares, ex-tesoureiro do PT]. Em Veja. Edição 2.001 . 28/03/07. P. 50. São Paulo: Editora Abril, 2007-2001.

WOJTYLA, Karol [Papa João Paulo II] ( ódigo de Direito Canônico [CDC]. Traduzido por João Corso et alii, com revisão e redação final de Tarcísio Ariovaldo do Amaral. São Paulo: Edições Loyola, 1983. 